\title{
Debt Capacity, Cost of Debt, and Corporate Insurance
}

\author{
Hong Zou and Mike B. Adams*
}

\begin{abstract}
Using a unique insurance dataset for a sample of Chinese publicly listed companies for the period 1997 through 2003, this study tests the simultaneous linkages between debt capacity, cost of debt, and corporate property insurance. Our results suggest that, on the one hand, a higher cost of debt appears to motivate the use of more property insurance, but high leverage alone does not lead to the purchase of more property insurance. The latter finding might reflect the unique institutional setting of China, for example, where there is a low chance of legally enforced company liquidation. Also, there is evidence that leverage can interact with tangible assets intensity and exert a positive conjoint effect on the corporate purchase of property insurance. On the other hand, we find evidence that supports that property insurance helps expand insuring firms' debt capacity and helps lower their borrowing costs. However, the moderate evidence on the cost reduction effect suggests that lowering the borrowing cost is likely to be a concern secondary to facilitating corporate borrowing and thereby expanding debt capacity in corporate property insurance decisions in China. Overall, we conclude that debt capacity, cost of debt, and corporate insurance appear to be simultaneously related.
\end{abstract}

\section{Introduction}

Over the last two decades, researchers have made significant progress in understanding the conundrum of why large and widely held corporations engage in costly risk management via the use of derivatives and/or insurance. While many studies have empirically examined the determinants of corporate use of financial

*Zou, hongzou@cityu.edu.hk, Department of Economics and Finance, City University of Hong Kong, 83 Tat Chee Avenue, Kowloon Tong, Kowloon, Hong Kong, China; Adams, m.b.adams@ swansea.ac.uk, School of Business and Economics, University of Wales, Swansea, SA2 8PP, U.K. We thank Paul Malatesta (the editor) and Ronald Masulis (associate editor and referee) for the insightful comments that significantly improved the paper. The paper further benefited from the suggestions of David Ashton, Mike Buckle, Simin Chen, Phil Hardwick, Rob Hoyt, Tong Jiao, Gang Wei, Jason Xiao, Tong Yu, and seminar participants at the Guanghua School of Management, Peking University, China, the 2005 University of Wales Accounting and Finance Colloquium, Gregynog, UK, School of Business and Economics, Umeå University, Sweden, and the 2005 World Risk and Insurance Economics Congress Conference, Salt Lake City, UT, U.S. The assistance of Jing Bian, Wei Cui, and Dan Ye in data collection is greatly appreciated. Zou acknowledges the financial support obtained from the Association of British Insurers and the Research and Postgraduate Studies Panel of Lingnan University (Grant No. DB04A4). We also thank Kenny Lin, Jiwei Wang, and Donghui Wu for their assistance with data gathering. However, the usual disclaimer applies. 
derivatives (e.g., see Mian (1996), Graham and Rogers (2002)), similar studies of corporate purchases of insurance have been relatively sparse. ${ }^{1}$ This is largely due to the fact that companies in developed markets such as the U.S. are required to disclose their derivatives positions in annual reports, while there is no such requirement concerning insurance purchases. On the other hand, Schmit and Roth (1990) report that the corporate risk management literature has paid little attention to the effects of corporate risk management on other financial management decisions, such as debt policy, despite their potential interrelation (e.g., see Smith (1986)). ${ }^{2}$

This study contributes to our understanding of the managerial incentives for corporate insurance by focusing on the simultaneous linkages between firms' debt capacity, cost of debt, and the voluntary use of property insurance in the People's Republic of China (PRC). ${ }^{3}$ Specifically, we seek to answer two interrelated questions. First, do firms' indebtedness and cost of debt motivate the use of insurance? Second, does insurance in turn affect firms' debt capacity and cost of debt?

Insight into these questions is important for at least four reasons. First, Graham and Rogers (2002) report that debt motivates the corporate use of financial derivatives and that using such instruments helps expand the debt capacity of hedging firms. Given the contractual and other differences between insurance and derivatives, it would be interesting to see whether this relation also holds in the context of insurance. Unlike financial derivatives, insurance cannot be used for speculation and therefore an insurance-based study like ours potentially provides a cleaner test of the relation between debt and corporate risk management.

Second, prior insurance studies (e.g., Mayers and Smith (1990), Yamori (1999), Hoyt and Khang (2000), and Zou and Adams (2006)) have generally taken corporate financial variables (e.g., leverage) as exogenous to risk management decisions. As a result, these studies may potentially suffer from simultaneous equation bias.

Third, the extant literature (e.g., Thakor (1982), Grace and Rebello (1993), and Huberman (1997)) postulates that in states of information uncertainty about future firm-specific risks, insurance could help company managers lower borrowing costs and make positive net present value investments. Indeed, Cole and Of-

\footnotetext{
${ }^{1}$ The determinants of the corporate use of derivatives are not necessarily the same as those of using insurance. For example, economies of scale are well pronounced in derivatives trading because of the high set-up costs, but less important in insurance (Mayers and Smith (1990)). Five main prior studies (Mayers and Smith (1990), Yamori (1999), Hoyt and Khang (2000), Zou, Adams, and Buckle (2003), and Zou and Adams (2006)) have examined the determinants of corporate insurance in different jurisdictions. Their results suggest that ownership structure, leverage, firm size, growth opportunities, managerial compensation, and regulatory status appear to be important factors affecting corporate insurance.

${ }^{2}$ Guay (1999) examines the impact of derivatives' use on firms' business risks among new derivatives users and documents a decline in firm-specific risks over time. Allayannis and Ofek (2001) demonstrate that using derivatives helps reduce hedgers' currency exposure. Graham and Rogers (2002) test the tax incentives for derivatives hedging and show that the use of derivatives helps increase hedging firms' debt capacity and helps reduce expected tax liabilities.

${ }^{3}$ Our definition of property insurance covers indemnity for losses in physical assets (e.g. fixed assets and inventory) due to fire, theft, and environmental perils (e.g., floods, storm damage, and earthquakes). Undeveloped property (mainly the right to use land) is treated as an intangible asset under Chinese accounting standards and so it is not insurable. Commercial property insurance in China is voluntary.
} 
ficer (1981) and Kidwell, Sorensen, and Wachowicz (1987) cite evidence on the interest benefits of financial guarantee insurance for issuers of U.S. municipal bonds. However, these two studies only examine the relation between a narrowly defined contractual form of insurance and a specific class of corporate borrowing. This study, in contrast, focuses on the simultaneous linkage between the cost of broadly defined debt (including bank loans and other types of corporate borrowings) and property insurance - a commonly used risk management mechanism. Therefore, our study provides a more general context for investigating the corporate debt-insurance relation.

Fourth, given the theoretical linkage between the cost of debt and property insurance, it is surprising to note that none of the prior studies on the determinants of corporate insurance considered the cost of debt as a potential covariate. We contribute to the literature by showing that lowering the cost of debt is a motivating factor for corporate property insurance decisions in China.

In addition to data availability, we focus on China for three other reasons. First, China provides an interesting setting for this study, since many Chinese firms rely heavily on bank financing as equity and bond issues are tightly regulated (see Section II). However, Chinese commercial lenders (particularly State-owned banks) generally face higher credit risks than lenders in developed countries as the prevalence of State ownership and the low likelihood of company liquidation may induce borrowers' moral hazard problems (Gul (1999), Tian (2001), and Wei, Xie, and Zhang (2005)).

Second, we believe that understanding corporate financing and risk management decisions in China is important because it is a large and fast growing economy and the largest recipient of foreign direct investment in the world (Sun and Tong (2003)). China's rapidly expanding capital markets and the increasing number of Chinese firms seeking overseas listings have offered international investors increased prospects for risk diversification. ${ }^{4}$ However, Lee and Rui (2000) observe that a key inhibitor to the efficient allocation of capital is the lack of knowledge among investors of the operations of Chinese publicly listed companies (PLCs). Indeed, the recent improper trading of derivatives in the Singaporelisted China Aviation Oil (CAO) Ltd. caused a loss of U.S.\$550 million for international investors and creditors. ${ }^{5}$

Third, Chinese PLCs are also unique in terms of the presence of substantive State share ownership — a feature rarely observed elsewhere (Gul (1999), Wei et al. (2005)). For example, State ownership represents roughly one-third of total shares outstanding and is present in about $90 \%$ of Chinese PLCs (China Securities Regulatory Commission (CSRC) database (2000)). Accordingly, the role of State ownership in affecting corporate insurance decisions in China is likely to be of interest to policy makers, investors, and others with an economic interest in the Chinese economy.

\footnotetext{
${ }^{4}$ Indeed, the Chinese stock market with about 1,100 quoted firms and a total market capitalization of about U.S. $\$ 590$ billion at the end of 2000 was ranked by Goldman Sachs (2001) as the most important emerging stock market in the world and the second largest market in Asia after Japan. In order to provide another channel for foreign investors to invest in the rapidly expanding Chinese capital markets, China introduced the system of qualified foreign institutional investors (QFII) in 2002.

${ }^{5}$ See http://www.bloomberg.com/apps/news?pid=10000080\&sid=aqEPmLvSBrFc\&refer=asia.
} 
Our results suggest that on the one hand, a high cost of debt appears to motivate the use of property insurance, but high leverage alone does not lead to the purchase of more property insurance. The latter finding might reflect the unique institutional setting of China, for example, the low probability of legally enforced company liquidations. Also, there is evidence that leverage and tangible assets intensity can interact and exert a positive conjoint effect on the corporate purchase of property insurance. On the other hand, we find evidence supporting the hypothesis that property insurance helps expand insuring firms' debt capacity and lower their borrowing costs. However, the limited evidence on the cost reduction effect suggests that lowering the borrowing cost is likely to be a concern secondary to facilitating corporate borrowings and thereby expanding debt capacity in making corporate property insurance decisions in China. Indeed, buying insurance can still be optimal even when the savings in lowering the cost of debt do not exceed the insurance premium given other benefits of insurance (e.g., expanded debt capacity, reduced bankruptcy, and financial distress costs). Overall, we find that debt capacity, cost of debt, and corporate insurance are simultaneously related. Our findings are thus consistent with the view that insurance is an integral part of corporate financial policies (e.g., see Smith (1986)).

The remainder of the paper is organized as follows. Section II describes briefly the role of insurance and corporate financing in China, while Section III formulates our main hypotheses. Section IV covers our research design, including the regression procedures employed, control variables, and data description. Section V discusses our main findings and the results of sensitivity tests, while Section VI concludes the paper.

\section{Corporate Financing and Insurance in China}

The establishment of the Shanghai Stock Exchange (SHSE) and the Shenzhen Stock Exchange (SZSE) in the early 1990s marked the beginning of a hybrid of debt and equity financing in the Chinese corporate sector (Ma (1998)). Since then the sale of equity to the public has been tightly controlled (Chen and Yuan (2004)). Until recently, China practiced a quota-based system for initial public offerings (IPOs). Each year the State set a total national quota on new equity issues; quotas were then allocated to various provinces and government ministries for selecting firms to issue shares. As the quota is limited relative to demand, only a small proportion of enterprises passed the screening process and undertook IPOs. For seasoned equity issues, only rights offerings were allowed in China until the regulatory reforms of 2000. Firms applying for equity issues had to go through a lengthy screening process that included financial performance (e.g., return on equity $(\mathrm{ROE})^{6}$ ) and non-financial assessments (e.g., at least a one-year gap since its last equity issue and no record of breaking the law) (Chen and Yuan (2004)). Consequently, many Chinese firms had to rely on debt financing, particularly bank loans, since bond issues were subject to tight controls (Sun and Tong (2003), Chen (2004)). This situation means that debt capacity and the cost of debt are poten-

\footnotetext{
${ }^{6}$ For example, during 1997-1999, a Chinese firm eligible for a rights issue must report a ROE of $\geq 10 \%$ in each of the three years prior to the year of application.
} 
tially important factors in management decision making in the Chinese corporate sector.

In China, non-performing loans currently account for about $25 \%$ of Stateowned banks' total outstanding loans (Sun and Tong (2003)). Indeed, for social and political reasons (e.g., with regard to maintaining employment and social stability), the Chinese government (national and local) has been reluctant to bankrupt State-owned enterprises (SOEs). The CSRC only started to delist financially troubled companies in 2001, but so far none of these companies have been formally liquidated. Consequently, the presence of large blocks of State ownership may induce moral hazard effects among borrowers (e.g., in terms of the reluctance for managers to commit to loan repayment schedules given the low chance of legally enforced liquidation), thereby increasing credit risks for lenders (Sun and Tong (2003)). Additionally, China's lack of comprehensive and reliable corporate credit ratings data available to lenders in making loan decisions further increases credit risks.

Given the higher credit risks in China, Chinese banks are expected to have added incentives to request borrower risk reduction activities, including requiring borrowers to provide adequate collateral and/or insurance coverage, in order to lower credit risks. Indeed, a series of drastic market reforms in the banking sector started in the early 1990s have stripped away the non-commercial responsibilities of State-owned banks, strengthened bank risk management and financial controls, and enhanced the accountability of loan decisions. ${ }^{7}$ China's entry into the World Trade Organization (WTO) has also introduced strong competition by large and reputable foreign banks. As a result of these reforms, State-owned banks can be viewed as market conscious commercial entities (Pei (1998), Li, Liu, Liu, and Whitmore (2001)). Li et al. (2001) also note that private and joint stock banks in China, which represent about $40 \%$ of banking businesses, are fully commercially operated and, thus, they are ostensibly no different from their Western counterparts in their focus on profitability and risk management.

Froot, Scharfstein, and Stein (1993) report that insurance is an important post-loss financing mechanism in companies; this is also the case in China (Zou et al. (2003)). Ma, Lin, and Ma (1998) report that the corporate demand for insurance in the PRC is to a large extent driven by the ongoing corporate reforms that began in 1978. Such market reforms have granted Chinese managers discretion over business decisions (including insurance decisions) and have significantly weakened corporate affiliations (including financial links) with government agencies (Ma (1998)). Furthermore, the public flotation of SOEs has introduced multiple stakeholders (e.g., private individuals, foreign and institutional investors) into Chinese PLCs. As a result, the accountability of Chinese managers has been greatly enhanced so that they now have greater incentives to consider commercial risk management options (e.g., insurance) than has hitherto been the case (Ma et al. (1998)). The general lack of risk management expertise and limited risk management alternatives (e.g., financial derivatives) in China has further encouraged managers to consider transferring some downside business risks (like unanticipated property losses) through the insurance market (Zou et al. (2003)).

\footnotetext{
${ }^{7}$ For details of the banking reform in China, please refer to Pei (1998) and Li et al. (2001).
} 


\section{Hypotheses Development}

\section{A. Leverage and Property Insurance}

Two types of debt-related costs - the expected costs of financial distress and the agency costs arising from shareholder-debtholder conflicts-may induce firms with high leverage to insure (Mayers and Smith (1982)).

First, firms with high leverage are likely to have higher expected costs of financial distress (both direct and indirect) than firms with low leverage. As a post-loss financing mechanism, insurance can mitigate the risk of severe cash shortfalls following accidental loss events. Although Chinese PLCs are rarely liquidated, this does not mean that they are free from the costs of financial distress. Zou et al. (2003) argue that for Chinese PLCs such costs are mainly manifest in the form of indirect costs associated with, for example, being disqualified from raising equity capital, potential regulatory actions, the threat of takeover from the corporate control market, and the loss of key customers and business suppliers. For example, a major uninsured loss may result in a failure to meet the CSRC's profitability threshold for issuing public equity. The CSRC also requires that the shares of firms reporting a loss for three consecutive years be subject to various trading restrictions (e.g., one trading day per week and a narrow price band of $\pm 5 \%$ ). If the financial situation of such firms does not improve within one year, they will be delisted. The managers of a loss making Chinese firm may also be subject to the disciplining effects of the market for corporate control.

Different from the market for corporate control in the West, the main threat to PLCs in China often comes from local government agencies that are controlling shareholders in many companies (Zou et al. (2003)). Due to concerns about local unemployment and the potential loss of tax revenues, local government officials often have incentives to negotiate the transfer of (non-publicly tradable Stateheld) shares in perennial loss making companies to other parties. As a result, incumbent management is often replaced following a change in the controlling shareholder. Indeed, Firth, Fung, and Rui (2002) report that management turnover in Chinese PLCs was negatively related to firms' financial performance during the period 1998 through 2000. Therefore, we argue that the indirect costs of financial distress may motivate managers in firms with high leverage to insure their assets. In fact, Warner (1977) argues that the indirect costs of financial distress are often greater than the direct costs such as liquidation and legal fees.

Second, the underinvestment problem may occur in firms with high leverage after an accidental loss because shareholders and managers fear that the benefits of reinvestment in damaged or lost assets accrue mainly to debtholders with fixed claims (Mayers and Smith (1982)). In China, government agencies as large shareholders are unlikely to exercise their "default put option" and liquidate a firm suffering from a major uninsured loss. However, company managers may choose to underinvest in potentially positive net present value reinvestment projects. This is because such underinvestment may prevent the majority of potential gains from being captured by debtholders, thereby leaving more funds available for managerial perquisite consumption and "empire building." This is possible in China as insiders' control is often strong in State-controlled PLCs, given that government 
bureaucrats have few financial incentives to closely oversee management (Xu and Wang (1999)). Mayers and Smith (1982) note that insurance can help alleviate the underinvestment incentives of shareholders in firms with high leverage. For example, insurance can help secure funding for the replacement of key manufacturing and/or office facilities damaged in insured events such as fires, storms, and floods. Therefore, our first hypothesis is:

H1a. Ceteris paribus, companies with higher leverage are likely to purchase more property insurance than companies with lower leverage.

As the purchase of property insurance in firms with high leverage may be conditioned on their insurable physical assets, we also include an interaction term between leverage and the tangible assets ratio and expect the interaction term to be positively correlated with the purchase of insurance. Consequently, a subsidiary hypothesis is:

H1b. Ceteris paribus, the insurance-debt relation is likely to increase with the amount of tangible assets.

Leland (1998) argues that risk management can help reduce the financial risk of a firm and thereby expand its debt-bearing capacity. Indeed, Graham and Rogers (2002) find supporting evidence for this contention using financial derivatives data from the U.S. corporate sector. The insurance of collaterized assets at the time when debt is issued means that the likelihood of future loan losses can be reduced and that as a consequence of the lower default risk, the borrower can increase its debt capacity given the larger expected collateral value, net of expected bankruptcy costs. The lender is also likely to charge the borrower a lower interest rate in a competitive market in light of the existence of insurance coverage. If the borrower takes out property insurance after the loan is granted, the lender gains by facing lower expected losses for the same interest risk premium. With lowered expected bankruptcy costs, the borrower may be able to renegotiate with the current lender and/or approach other new lenders on more favorable loan terms (e.g., a lower interest rate and/or larger loan size). Therefore, our second hypothesis is:

H2. Ceteris paribus, companies carrying more property insurance are likely to have a higher debt capacity than companies carrying less property insurance.

\section{B. Cost of Debt and Property Insurance}

Thakor (1982) develops adverse selection-based models that seek to explain the (potentially costly) use of insurance in light of managerial trade-offs with other decisions such as financing and investment choices. In his model, Thakor (1982) contends that information production by insurers acting as intermediaries between borrowers and lenders helps facilitate debt transactions by providing lenders with assurance as to the future security of their loan. As a result, the purchase of property insurance can help reduce the costs that lenders face in screening borrowers' creditworthiness before the debt is issued and in monitoring their compliance with debt covenants after the debt is issued (Grace and Rebello (1993)). Therefore, if there is an appropriate insurance program in the borrowing firm, the credit risks facing corporate lenders can be significantly reduced. Corporate 
lenders, in turn, might agree to grant loans at terms and conditions that reduce borrowers' cost of debt. This possibility may be reinforced by market competition for creditworthy clients among banks in China. As a result, a borrower could purchase property insurance as a bonding mechanism to mitigate lenders' concerns about the probability of bankruptcy following unanticipated losses; by shifting hazard risks from debtholders to insurance companies, property insurance may help reduce the market cost of debt (Thakor (1982), Grillet (1992), Grace and Rebello (1993), and Huberman (1997)). Property insurance purchases can be beneficial when the savings in interest payments exceed the premium paid. However, it is important to note that insurance may still be optimal for borrowers even if the savings in interest payments are less than the premiums. This is because in addition to a possible reduction in the interest rate, insurance protection can have other benefits (e.g., reduced costs of financial distress and lowered agency costs of the underinvestment problem).$^{8}$ Our third and fourth hypotheses are:

H3. Ceteris paribus, firms facing a higher cost of borrowing are likely to insure their assets to a greater extent than firms with a lower cost of borrowing.

H4. Ceteris paribus, firms carrying more property insurance are likely to have a lower cost of borrowing than firms carrying less property insurance.

\section{Research Design}

\section{A. Models}

To test our hypotheses, we adopt the following system of simultaneous equation models:

$$
\begin{aligned}
I N S & =f\{\text { DEBT, COD, Control Variables }\}+\varphi \\
D E B T & =f\{I N S, \text { COD, Control Variables }\}+v, \\
C O D & =f\{I N S, D E B T, \text { Control Variables }\}+\gamma
\end{aligned}
$$

INS is the amount of property insurance purchased. Following Zou et al. (2003) and Zou and Adams (2006), INS is defined as the total annual corporate spending on property insurance scaled by the prior year-end book value of tangible assets (e.g., fixed assets and inventory). ${ }^{9}$ As in Graham and Rogers (2002), debt capacity $(D E B T)$ is measured by the book value of total (long- and shortterm) debt $\div$ total assets. $C O D$ is a firm's interest cost per Renminbi (RMB) of debt used. ${ }^{10}$ As in Jun and Jen (2003) and Pittman and Fortin (2004), we measure $C O D$ as (interest expense charged to the P\&L account + capitalized interests) $\div$ the book value of total debt. ${ }^{11}$

\footnotetext{
${ }^{8}$ We thank the referee for suggesting this point.

${ }^{9} \mathrm{We}$ assume that property insurance decisions are made at the beginning of the accounting year. Property insurance contracts are normally valid for one year and renewable annually thereafter.

${ }^{10}$ Renminbi (RMB) is the Chinese currency.

${ }^{11}$ As Chinese company accounting disclosures do not give a breakdown of interest charges relating to each class of debt contract (e.g., bank loans, bonds, notes payable, and borrowing from non-bank institutions), we use the ratio of interest to total debt as our preferred measure of the cost of debt.
} 
We control for industry effects in two ways. First, we adjust $D E B T$ and $C O D$ by subtracting their respective industry median from a firm/year's debt and cost of debt ratio. Industry medians are calculated on the basis of the primary three-digit industry code as prescribed by the 2001 CSRC industry classification-B. Second, we also include 20 industry dummies determined by the two-digit industry code in equations (1)-(3). ${ }^{12}$

We expect that in equation (2), firms with a higher cost of borrowing are likely to have lower leverage than firms with a lower borrowing cost. We also predict that in equation (3), leverage has a positive impact on the cost of borrowing for two reasons. First, firms with higher leverage are more susceptible to financial distress and so have a greater risk of debt default (Petersen and Rajan (1994), Johnson (1997)). Second, shareholders in firms with high leverage are expected to have greater incentives to engage in asset substitution and underinvestment that is potentially harmful to debtholders' economic interests (Jensen and Meckling (1976)).

\section{B. Control Variables and Measurement}

We follow the extant literature and control for other major determinants of corporate insurance, capital structure, and the cost of debt. The motivation and measurement of these variables are briefly discussed below. ${ }^{13}$

\section{Other Determinants of Property Insurance}

Tangible Assets Intensity. Tangible assets intensity is included to control for the impact of differences in asset structure on property insurance purchases. Rajan and Zingales (1995) suggest that firms with more tangible assets are able to provide more collateral for borrowing and so they are likely to purchase more property insurance than others. Tangible assets intensity is defined as the ratio of the book value of tangible assets (i.e., fixed assets and inventory) to the book value of total assets. ${ }^{14}$

Growth Opportunities. Firms with more growth opportunities tend to be riskier than firms with fewer growth opportunities and so they may have relatively higher costs of financial distress (Myers (1984)). Such firms are also expected to face a higher cost of external financing due to a more severe information asymmetry problem about the future quality of new projects (Myers and Majluf (1984)). Insurance not only reduces the risk of bankruptcy and thereby financial distress costs, but also lowers the incidence of cash flow shortfalls (following a major accidental loss) that could trigger a reduction in value-enhancing investments (Froot et al. (1993)). The presence of insurance may also help reduce the cost arising from a fire sale of assets when a firm has a cash flow shortfall. We follow Graham and Rogers (2002) and use the ratio of capital expenditures (in

\footnotetext{
${ }^{12}$ We include in the regression models industry dummies determined by the two-digit rather than the three-digit industry code to keep the number of industry dummies manageable and conserve degrees of freedom. Refer to the Appendix for further details.

${ }^{13}$ In an early version of the paper, we also include a tax convexity measure prescribed by Graham (1996) and Barton (2001) in equation (1), but as in Graham and Rogers (2002) we find it insignificant.

${ }^{14}$ As noted earlier, undeveloped properties (mainly the right to use land) in China are treated as intangible assets and so are not included in the tangible assets ratio.
} 
acquiring fixed assets and long-term intangible assets) to total assets as a proxy. A high ratio of capital expenditure to total assets is likely to indicate greater future growth opportunities than otherwise. We expect a positive relation between growth opportunities and property insurance coverage. ${ }^{15}$

Firm Size. Small companies tend to buy relatively more insurance than large companies because the expected direct costs of financial distress are not proportional to size (Warner (1977)) and small companies can gain more from insurers' real services, e.g., advice on loss prevention and control (Hoyt and Khang (2000)). We measure firm size as the natural logarithm of total assets at 1997 constant prices.

Managerial Ownership. Two arguments explain the effects of managerial share ownership on corporate insurance decisions. The managerial risk aversion hypothesis argues that managers with a high level of stock ownership are likely to insure more in order to reduce their (underdiversified) wealth risk (e.g., see Smith and Stulz (1985)). ${ }^{16}$ In contrast, the incentive-alignment hypothesis posits that as managers' stock ownership increases, their economic interest is likely to become more closely aligned with that of shareholders, thereby motivating them to maximize the value of their shares (viewed as a call option on the firm's assets) by increasing the level of firm risk (Saunders, Strock, and Travlos (1990)). This implies a negative relation between the amount of insurance held by firms and the level of managerial ownership. Additionally, insurance can help managers maximize firm value by lowering potential financial distress costs and mitigating the underinvestment problem (Mayers and Smith (1982)). Overall, the effect of managerial ownership on property insurance is an empirical issue. In the spirit of Hall and Murphy (2002), we measure managerial ownership as the natural logarithm of the market value of managerial shareholdings. One RMB is added in order to facilitate the log transformation of zero values. The market value is computed using a monthly average share price in the year concerned.

State Ownership. Zou et al. (2003) predict that State shareholdings should discourage managers from taking out insurance, as government shareholders may provide financial assistance (e.g., subsidies and/or loan support) and other help (e.g., business contacts) to the firms in which they retain a large stake (Gul (1999), Tian (2001), and Wei et al. (2005)). On the other hand, State-owned PLCs are rarely liquidated, so managerial incentives to insure asset-loss risks can be reduced because of the possible bailout by the State in the event of severe property losses. However, Zou et al. (2003) find no empirical support for this view.

We advance an alternative argument-the political incentive hypothesisthat predicts State ownership may have a positive effect on corporate insurance. $\mathrm{Xu}$ and Wang (1999) argue that managers of SOEs are essentially no different from government officials who pursue self-interested political careers. Therefore, SOE managers could be motivated to insure company assets because an uninsured

\footnotetext{
${ }^{15}$ Using the market-to-book value ratio as a growth proxy can be problematical in China given that about two-thirds of shares held by the State and some institutional investors are not publicly tradable and the nascent Chinese stock markets tend to be very volatile. The use of other growth measures like research and development $(\mathrm{R} \& \mathrm{D})$ expenditures is also precluded by the lack of data.

${ }^{16}$ We focus on managerial ordinary (common) stock ownership because equity-option plans are currently undeveloped in China (e.g., see Firth et al. (2002)).
} 
major loss may be counted as functional incompetence and/or a neglect of duty, which would have an adverse effect on their future career prospects. Additionally, a lack of corporate liquidation in China does not protect creditors from future losses due to loan default, and as such, debtholders might still demand property insurance even in the presence of substantial government shareholdings. The risk of loan default and reliance on uninsured collateralized assets also reduces the ability of managers in State-controlled companies to access debt financing from sources other than State-run banks (which may charge higher rates of interest, impose restrictive lending conditions, and/or offer loans of smaller size). As a result, firms with substantial State ownership may still need to insure their assets. We measure State shareholdings as the ratio of the number of shares held by the State to the total number of shares outstanding.

Fiscal Subsidies. While market reforms have significantly weakened Chinese companies' affiliations with government agencies, some companies still receive fiscal subsidies from the local or national government (often in the form of tax rebates and occasionally in the form of direct subsidies from a local finance bureau when the firm is on the verge of being disqualified for future equity issues or delisted). These fiscal benefits may discourage managers from insuring potential asset-loss risks. Fiscal subsidies are measured by total annual subsidies received from government agencies scaled by annual sales income. ${ }^{17}$

Financial Constraints. Several studies (e.g., Haushalter (2000), Graham and Rogers (2002), and Zou and Adams (2006)) report that financial constraints may limit corporate risk management activities. We control for this possibility by including the quick ratio, defined as (current assets - inventory) $\div$ current liabilities, in our analysis. A positive and significant coefficient on the quick ratio is consistent with the financial constraint argument. However, it is also possible that firms with a low quick ratio may face a high cost of debt and need to provide insured collateral. Additionally, the post-loss financing function of insurance may be more valuable for firms with financial constraints than firms with a high liquidity. This line of reasoning suggests a negative effect of the quick ratio on the purchase of property insurance.

Secured Debt. When a firm has secured debt, it is common to carry property insurance on the tangible assets serving as collaterals. We therefore explicitly control for this possibility by including the proportion of secured debt (i.e., the year-end amount of secured debt $\div$ total liabilities) in our analysis. ${ }^{18}$

Firms Located in the Eastern Coast. To meet the exclusion restrictions that are necessary for identification in the Heckman model (e.g., see Villalonga and Amit (2006)), we follow Zou and Adams (2006) and include a geographical location variable (with 1 denoting firms from China's Eastern coast and 0 for firms from inland areas) in the insurance probit model, but exclude it from the insurance volume model. The rationale is that managers of companies located in the more

\footnotetext{
${ }^{17}$ We scale subsidies by annual sales rather than by taxable income because some firms in our sample reported negative taxable income and Chinese firms are reported to manage reported earnings through the use of one-time extraordinary items (Chen and Yuan (2004)).

${ }^{18}$ Corporate debt is sometimes secured on the right to use land that is not insurable in China. Furthermore, a breakdown of secured debt by types of collaterized assets is not available from public sources in China. Accordingly, our proxy for secured debt may be a noisy measure.
} 
economically developed Eastern coast of China (e.g., Beijing, Shanghai, Guangdong) tend to have a higher level of risk management awareness and so are more likely to use property insurance than their counterparts in companies located in inland areas. However, the literature is not clear as to whether geographical location influences the amount of property insurance. As such, geographical location is used as a selectivity bias identifier in our insurance probit model (see Section IV.C.2).

Industry Membership. We control for two types of firms that may have an intrinsically high demand for property insurance. ${ }^{19}$ First, businesses including the manufacturing of chemicals, plastics and rubber, oil and gas extraction/refining, coal mining, and metallurgical engineering are prone to accidental losses (hereafter termed as "high property risk firms"). The second type includes firms that are likely to have relatively high financial distress costs compared to other firms. For example, high growth firms whose firm value comprises mainly intangible growth opportunities are likely to have high financial distress costs relative to firms that proportionately have more assets-in-place. This is because intangible growth opportunities are only valuable when a firm remains a going concern (Myers (1984)). We follow Ritter and Welch ((2002), p. 1801) and define such firms as hi-tech stock firms, which include Internet companies, firms engaging in the manufacturing of computer software and hardware, communication equipment, pharmaceuticals, and bio-tech firms. We predict that if property insurance helps mitigate the underinvestment problem of high growth firms, such firms are expected to purchase more property insurance than other firms, other things being equal. In recognizing the possibility that the purchase of property insurance by hi-tech stock firms may be conditioned on the amount of tangible assets, we also include an interaction term between the hi-tech stock dummy and tangible asset intensity. All else equal, the interaction term is expected to have a positive effect on the purchase of property insurance.

Mayers and Smith (1982) argue that firms in highly regulated industries (e.g., utilities) may purchase more property insurance than less regulated firms because of pressure from industry regulators and/or their ability to pass insurance costs onto customers. We therefore include a dummy for regulated utilities and expect it to be positively correlated with the use of property insurance.

Moreover, 20 industry dummies, categorized by the two-digit industry code of the 2001 CSRC industry classification-B, are also included in the insurance, debt ratio, and cost of debt equations as further controls for industry effects.

\section{Other Determinants of Debt Capacity}

We include five commonly recognized determinants of corporate financial leverage (i.e., firm size, tangible assets intensity, growth opportunities, profitability, and non-debt tax shields) and one institutional factor (i.e., State ownership) in our analysis. Two different capital structure theories - the static trade-off model and the pecking order hypothesis $(\mathrm{POH})$ - generally have different predictions on the effect of these factors on leverage (Rajan and Zingales (1995), Fama and French (2002), and Frank and Goyal (2003)). For example, the static trade-off

${ }^{19}$ We thank the referee for this suggestion. 
model predicts that large and profitable companies and firms with high tangible assets intensity and/or less growth opportunities are likely to have higher leverage than other firms because of their better access to debt markets, greater exposure to taxes, and likely lower agency costs associated with the debt overhang problem. In contrast, the $\mathrm{POH}$ posits that large firms, firms with high tangible assets intensity and/or less growth opportunities tend to face less information asymmetry, and so they are likely to use more equity instead of debt than other firms. The $\mathrm{POH}$ also predicts that because profitable firms are more capable of securing internal financing via retained profits, they are less likely to use external debt than other firms (Fama and French (2002)). To be cautious about the confounding effects of earnings management in China, we use annual operating profit, instead of net profit, which we divide by the prior year-end book value of total assets as a measure of profitability.

Non-debt tax shields (e.g., depreciation) may offset the tax advantages afforded by paying interest (Bradley, Jarrell, and Kim (1984)). As in Graham and Rogers (2002), we measure non-debt tax shields as annual sales and general and administrative (SG\&A) expenses (including depreciation but excluding interest) divided by sales income.

State Ownership. Gul (1999), Tian (2001), and Wei et al. (2005) note that in China, the State may provide assistance in helping firms in which it has a large block of shareholdings secure bank loans. Therefore, firms with more State ownership may have higher leverage than firms with less State ownership. However, firms with more State ownership may gain better access to the domestic stock markets given that in China the government's equity quota allocation is geared to SOEs. Therefore, we do not have an a priori expectation on the relation between State ownership and leverage.

Interest Coverage. We also control for the effect of the interest coverage ratio (a proxy for a borrower's ability to pay interest) on leverage. Firms with adequate interest coverage may be more likely to secure bank loans than firms with low interest coverage. However, such firms could be profitable and more likely to secure financing via retained profits rather than by borrowing. Therefore, the effect of interest coverage on leverage is ambiguous. The interest coverage ratio is defined as the ratio of earnings before interest, tax, and extraordinary items to annual total interest incurred. ${ }^{20}$

\section{Other Determinants of the Cost of Debt}

The following firm-specific characteristics and economy-wide factors that may affect the cost of debt are controlled for.

Firm Size, Age, and Tangible Assets Intensity. Large firms generally have greater financial strength and a lower default risk and therefore may pay a lower interest rate than small firms (Diamond (1984), Petersen and Rajan (1994)). Likewise, newly launched firms tend to be riskier and have a higher rate of failure than long-established firms (Leeth and Scott (1989)). Younger firms also have little reputational capital value to lose if their managers engage in behavior that is con-

\footnotetext{
${ }^{20}$ In China, banks are likely to pay more attention to a borrower's recurring income when evaluating credit risks than the bottom-line earnings figure due to concerns about managerial earnings manipulation.
} 
trary to lenders' interests (Johnson (1997)). Therefore, we expect that both firm size and age are inversely related to the cost of debt. Firm age is measured as the number of years since incorporation. Since firms with more tangibles assets may be able to provide more collateral and/or more property insurance, we therefore expect the tangible assets to total assets ratio is negatively related to the cost of debt.

Interest Coverage and Sales Growth. As in Petersen and Rajan (1994), the interest coverage ratio and sales growth rate are both expected to be negatively related to the cost of debt. The interest coverage ratio is defined previously and the sales growth ratio is calculated as year-on-year growth in sales income.

Prime Lending Rate. As in Petersen and Rajan (1994), we control for the influence of prime lending rates that are set by the Central Bank (the People's Bank of China (PBOC)) on firms' borrowing costs. We use the one- to three-year rate of bank loans issued by the PBOC in corresponding years as a proxy for the prime rate and expect it to have a positive effect on firms' borrowing costs.

State Ownership. As discussed in Section II, a high level of State ownership may expose lenders to a higher credit risk. Therefore, lenders may charge such firms a higher interest rate than normal. On the other hand, the government may exert its influence by assisting firms in which it retains a large stake to secure bank loans at favorable terms. Therefore, the effect of State ownership on firms' average borrowing costs is not clear.

Board Characteristics. Anderson, Mansi, and Reeb (2004) find that the cost of debt is inversely related to board independence, board size, and the independence of audit committees. They attribute these findings to the role of these corporate governance mechanisms in enhancing the reliability of financial reports. On the other hand, Yermack (1996) reports that large boards tend to reduce firm performance, which implies that firms with large boards may be associated with a higher cost of debt than those firms with smaller boards. ${ }^{21}$ As a result, we control for the effect of the proportion of independent directors on the board and board size (measured as the natural logarithm of the number of directors). Other things being equal, we expect the proportion of independent directors to be negatively related to the cost of debt, but the influence of board size on debt costs is not clear from the literature. ${ }^{22}$

Debt Structure. Different types of debt are likely to have different costs and so debt structure may affect the total interest cost of debt. For example, bank loans may be more expensive to use than notes payable and trade credits. As bank loans are a major source of corporate borrowing in China, we include the ratio of (long- and short-term) bank loans to total debt as an additional control variable and predict that it will have a positive impact on the overall cost of debt. ${ }^{23}$

\footnotetext{
${ }^{21}$ We thank the referee for suggesting this point.

${ }^{22}$ Few Chinese PLCs have established audit committees so far (e.g., see Wei et al. (2005)).

${ }^{23}$ Under Chinese accounting standards, liabilities arising from leasing are treated as "other (longterm) payables" and thus an integral part of total debt. In previous tests, we controlled for the proportion of bond, notes payable, accounts payable, and "other payables," but obtained similar results.
} 


\section{Sample}

\section{Construction of the Main Sample}

In selecting our main sample, we first impose the following restrictions.

i) A firm should not be in the financial services sector (i.e., banks, insurance, and securities companies) because they account and report under different rules and are generally active in the trading of risk management products/services.

ii) A firm should not have experienced any material company reorganizations in the sample period. Company reorganizations in China typically include asset swaps, debt transfer, and divestitures among associated companies. Such company reorganizations can dramatically change a firm's asset and debt structure and so could distort the interpretation of our results. ${ }^{24}$

iii) A firm/year should have all the accounting and share price information needed for the variables specified in equations (1)-(3).

We manually checked the annual reports of qualifying firms from 1997 through 2003, which represents the longest period for which full-text annual reports of Chinese PLCs were available at the time our study was carried out. We identified 2,016 firm/year observations reporting annual spending on commercial property insurance, which covers 707 firms. ${ }^{25}$

Company-specific share price data were extracted from DataStream and accounting information other than insurance spending and capitalized interest expenses was obtained from CSMAR Securities Research Database (developed by Shenzhen GTA Ltd. and Hong Kong Polytechnic University) and WIND Financial Information System (developed by Shanghai Wind Ltd.). The former is often used by academics and the latter is a leading data provider to institutional investors. The two data sources were cross-checked to ensure data consistency.

\section{Sample Selectivity Bias}

By focusing on Chinese PLCs (voluntarily) disclosing property insurance spending, our study potentially suffers from sample selectivity bias. Addressing this problem involves the identification of firms carrying no insurance. We obtained the non-insurance sample (i.e., 75 observations) for the period 1997 through 1999 from Zou and Adams (2006) who conducted a telephone-based survey of all Chinese PLCs. We also sent a simple email instrument to the designated representative responsible for information disclosures in all qualifying firms for the period 2000 through 2003 by asking whether these firms carried commercial property insurance. The name and email address of the designated representative of each firm are identified from the CSRC's official website. After three rounds of contacts (one initial contact and two follow-ups), we received replies from 122 firms (488 observations); this represents a response rate of approximately $9 \%$. Such a low response rate supports the view expressed by Roy, Walters, and Luk

\footnotetext{
${ }^{24}$ The materiality of asset reorganization is determined in this study by applying the official criteria laid down by the CSRC-i.e., more than a $30 \%$ change in the value of tangible assets.

${ }^{25}$ Several large Chinese PLCs, notably those from the oil and chemical industries, buy insurance from parent-run group insurance pools or captive insurance subsidiaries. Such internal insurance is different from external commercial insurance (e.g., insurance captives write very little, if any, third party risks business) and so such firms are excluded from our data set.
} 
(2001) that various political, social and cultural constraints in China make it difficult to conduct field-based data collection. After excluding firms/years "unclear about carrying insurance" and observations previously included in the insurance firms' sample identified from the annual reports, we were left with a usable dataset of 379 additional observations (of which 239 observations insured their assets and 140 observations did not). Combining this dataset with the 75 firms/years carrying no property insurance for the period 1997 through 1999, we end up with the sample detailed in Table 1.

TABLE 1

Sample Information

Table 1 presents sample information.

Firms carrying and disclosing insurance spending in annual reports

Firms carrying but not disclosing insurance spending in annual reports Subtotal

Firms carrying no property insurance Total

\begin{tabular}{r} 
No. of Obs. \\
\hline 2,016 \\
239 \\
2,255 \\
215 \\
2,470
\end{tabular}

Our study may face two types of sample selectivity. The first is whether a firm insures its assets or not and the second is whether a firm carrying property insurance chooses to disclose it in its annual report or not. Because a firm's decision on whether to purchase insurance and/or to disclose such purchase may not be random, selectivity bias can cause the error terms in our models to be correlated, thereby biasing the estimated regression parameters. Following Guedes and Opler (1996) and Pincus and Rajgopal (2002), we adopt a variant of the Heckman sample selection model. Specifically, we estimate two probit selection models (hereafter referred to as the "insurance probit" and the "disclosure probit" models, respectively) and generate the inverse Mills ratio from each probit. We then include the two inverse Mills ratios into our system of simultaneous equations as corrections for the potential sample selection bias. In the insurance probit model, the dependent variable is a dichotomous variable that takes the value of 1 for firms carrying insurance and 0 otherwise. Explanatory variables entering the insurance probit model are described in Section IV.B.1, with the Eastern coast dummy as the selection identifier. In the disclosure probit model, the dependent variable is a dichotomous variable that takes 1 if a firm carries property insurance and discloses it in the annual reports and 0 for otherwise.

While no prior study has examined the factors affecting the disclosure of insurance purchases, we include as explanatory variables those firm characteristics that are commonly cited as determinants of corporate voluntary disclosures (e.g., Chen and Jaggi (2000), Healy and Palepu (2001), and Xiao, Yang, and Chow (2004)), which includes firm size, profitability, risk factors (leverage and the quick ratio), (domestic) public share ownership, foreign ownership, the proportion of independent directors, and whether a firm is a conglomerate (denoted by 1). Domestic public share ownership is defined as the proportion of tradable Ashares. Foreign ownership is the sum of the proportion of foreign founder share ownership, (domestically traded) B-shares and (overseas traded) H-shares. The 
other variables are defined in Section IV.B. Given that in China corporate insurance spending is normally disclosed as a sub-item in the notes to unamortized expenses, a firm with high levels of amortized expenses is more likely to itemize its insurance spending (if any). We therefore include unamortized expenses (scaled by total assets) as a further explanatory variable for property insurance disclosure.

\section{Results}

\section{A. Sample Characteristics and Correlation Analysis}

Table 2 lists the descriptive statistics of the variables used. Consistent with Zou et al. (2003), the median of the property insurance to tangible assets ratio is about $0.1 \%$. In our sample, the proportion of firms/years carrying no property insurance is about $8.7 \%$ of the total number of observations and this is comparable to the figure of $11.2 \%$ reported in Zou and Adams (2006).

\section{TABLE 2}

Summary of Descriptive Statistics

Table 2 provides descriptive statistics for the variables used in the analysis. The meaning of each variable is selfexplanatory and calculation details are given in the Appendix. Presented statistics on DEBT and COD are based on raw data. The number of observations entering the insurance probit model, the disclosure probit model, and the secondstage system of simultaneous equations is 2,470,2,250, and 2,016 observations, respectively. Five observations are lost due to missing values in ownership variables in the disclosure probit model. The book value of total assets is expressed in 10,000 RMB and the market value of managerial shares is in RMB.

\begin{tabular}{|c|c|c|c|c|c|c|}
\hline Variables & Mean & Median & Std. Dev. & Min. & Max. & Obs. \\
\hline Insurance choice dummy & 0.910 & 1.000 & 0.282 & 0 & 1 & 2,470 \\
\hline Log(book value of assets) & 13.343 & 11.881 & 3.643 & 9.382 & 24.842 & 2,470 \\
\hline Debt to assets ratio (DEBT) & 0.458 & 0.456 & 0.173 & 0.018 & 0.999 & 2,470 \\
\hline Interest to debt ratio (COD) & 0.034 & 0.033 & 0.021 & 0.001 & 0.455 & 2,470 \\
\hline Tangible assets to assets ratio & 0.502 & 0.497 & 0.164 & 0.016 & 0.999 & 2,470 \\
\hline Capital expenditure to total assets ratio & 0.064 & 0.041 & 0.071 & 0.000 & 0.749 & 2,470 \\
\hline $\log (1+$ market value of managerial shares $)$ & 10.663 & 12.967 & 5.497 & 0.000 & 20.016 & 2,470 \\
\hline Fiscal subsidy to sales ratio & 0.012 & 0.000 & 0.098 & 0.000 & 2.532 & 2,470 \\
\hline Proportion of State shareholdings & 0.308 & 0.311 & 0.260 & 0.000 & 0.886 & 2,470 \\
\hline Quick ratio & 1.293 & 0.989 & 1.178 & 0.010 & 14.504 & 2,470 \\
\hline Secured debt to total debt ratio & 0.082 & 0.010 & 0.138 & 0.000 & 0.720 & 2,470 \\
\hline Eastern coast dummy & 0.529 & 1.000 & 0.499 & 0 & 1 & 2,470 \\
\hline Regulated utilities dummy & 0.080 & 0.000 & 0.266 & 0 & 1 & 2,470 \\
\hline Conglomerates dummy & 0.160 & 0.000 & 0.368 & 0 & 1 & 2,470 \\
\hline High property risk firms dummy & 0.230 & 0.000 & 0.424 & 0 & 1 & 2,470 \\
\hline Hi-tech stock dummy & 0.040 & 0.000 & 0.194 & 0 & 1 & 2,470 \\
\hline Insurance disclosure dummy & 0.896 & 1.000 & 0.302 & 0 & 1 & 2,250 \\
\hline Operating profit to assets & 0.031 & 0.035 & 0.064 & -0.642 & 0.311 & 2,250 \\
\hline Domestic public ownership & 0.348 & 0.342 & 0.136 & 0.000 & 1.000 & 2,250 \\
\hline Foreign ownership & 0.050 & 0.000 & 0.120 & 0.000 & 0.660 & 2,250 \\
\hline Proportion of independent directors & 0.102 & 0.000 & 0.141 & 0.000 & 0.556 & 2,250 \\
\hline Unamortized expenses to total assets ratio & 0.002 & 0.001 & 0.003 & 0.001 & 0.043 & 2,250 \\
\hline Insurance to tangible assets ratio (INS) & 0.002 & 0.001 & 0.003 & 0.0002 & 0.045 & 2,016 \\
\hline SG\&A expense & 0.192 & 0.129 & 0.446 & 0.008 & 14.198 & 2,016 \\
\hline Firm age (years) & 7.520 & 7.000 & 4.249 & 1.000 & 46.000 & 2,016 \\
\hline Sales growth ratio & 1.253 & 1.112 & 1.340 & 0.023 & 34.110 & 2,016 \\
\hline Prime lending rate & 0.065 & 0.059 & 0.015 & 0.055 & 0.107 & 2,016 \\
\hline Log of board size & 2.227 & 2.197 & 0.252 & 1.100 & 2.944 & 2,016 \\
\hline Bank loans to total debt ratio & 0.534 & 0.561 & 0.199 & 0.000 & 0.944 & 2,016 \\
\hline Interest coverage ratio & 36.189 & 2.262 & 653.5 & -47.5 & $24,244.2$ & 2,016 \\
\hline
\end{tabular}

On average, the total interest to debt ratio is roughly $3.3 \%$, which is less than the $5.9 \%$ median prime lending rate for bank loans over the sample period. This suggests that in China some non-bank debt (e.g., notes payable, trade credit) may 
bear a lower cost than bank loans. Indeed, bank loans on average represent about $53 \%$ of total debt, with the remainder of debt coming from other sources. Sample firms on average have a debt ratio of $46 \%$ and this figure is comparable to the $47 \%$ average for all Chinese PLCs in 1998 (Li et al. (2001)). Consistent with Chen (2004) and Zou and Xiao (2006), a further examination reveals that longterm bank loans only account for about $20 \%$ of total bank loans. Therefore, our sample firms tend to rely more on short- rather than long-term bank loans. This may reflect Chinese banks' caution in issuing (riskier) long-term loans and/or that Chinese PLCs rely increasingly on equity for financing long-term investments. ${ }^{26}$ Booth, Aivazian, Demirguc-Kunt, and Maksimovic (2001) also report that firms from 10 developing countries tend to have a greater dependence on short- rather than long-term debt.

In terms of ownership, the average shareholdings of the State and incumbent managers are $31 \%$ and $0.07 \%$, respectively-similar to the figures reported in prior studies (e.g., Tian (2001)). The average log of total assets (in 10,000 RMB) is 13.34 for our sample of firms, which is close to the average of 11.62 for all the firms over the 1997-2003 period reported in the CSMAR database. Therefore, our sample appears to be representative of Chinese PLCs.

The descriptive statistics also suggest that some variables (e.g., the interest to debt ratio, SG\&A expenditure, and the interest coverage ratio) have extreme values. For example, one observation has the interest to debt ratio equal to 0.455 (i.e., the maximum value) and two observations with the interest to debt ratio around 0.135 . To avoid the undesirable influence of the extreme values, we follow Pittman and Fortin (2004) and winsorize the above three variables at their respective 99.5 percentile value in our regressions. ${ }^{27}$

Table 3 presents the Pearson correlation coefficients between the endogenous variables and their covariates. ${ }^{28}$ The correlation coefficients of most explanatory variables of the insurance probit model are in the predicted directions. While most explanatory variables of the disclosure probit model exhibit significant correlations with the property insurance disclosure dummy, some of them are in a direction contrary to what was predicted. This may signify the unique feature of insurance disclosure. As expected, there are statistically significant correlations between the insurance to tangible assets ratio, the debt to assets ratio and the interest to debt ratio. However, a simple correlation analysis may mask the potential two-way linkages between variables.

\footnotetext{
${ }^{26}$ However, the long-term debt ratio may not give a true picture of the level of long-term debt since Chinese firms often use short-term debt on a rolling basis (Chen (2004), Xiao et al. (2004)).

${ }^{27}$ As reported in Section V.C, our results are qualitatively similar if we exclude rather than winsorize observations over the 99.5 percentile of each of the three variables. Overall, we find the extreme values seem to have important impacts on the results of some control variables in the debt equation, but do not affect the tenor of our major conclusions.

${ }^{28}$ The correlation coefficients between exogenous variables are not tabulated. Industry dummies 10,14 , and 19 are omitted from regression due to industry dummy 10 's high correlation with the high property risk firms dummy and industry dummies 14 and 19's high correlation with the high-tech stock dummy (see the Appendix). Otherwise, correlation coefficients are moderate. We also compute the variance inflation factor of each variable appearing in each model and they are all less than 3. Therefore, we conclude that multicollinearity is not a severe problem (see Kennedy (1998), p. 190).
} 
Table 3 presents the Pearson correlation coefficients between the dependent and independent variables in the insurance probit, disclosure probit, and the three models in the system of simultaneous equations. DEBT and COD are industry median-adjusted debt ratio and cost of debt. In the interest of saving space, correlation coefficients between (exogenous) independent variables are not tabulated. Industry dummies 10, 14, and 19 are omitted from regression due to industry dummy 10's high correlation with the high property risk firms dummy and industry dummies 14 and 19 's high correlation with the tech stock dummy (see Appendix). Otherwise, correlation coefficients among explanatory variables are moderate. We also compute the variance inflation factor of each variable appearing in each model and they are all less than $3 .{ }^{*},{ }^{* *}$, ${ }^{\star * \star}$ are statistically significant at the $0.10,0.05$, and 0.01 levels (two-tailed), respectively.

Insurance to tangible assets ratio (INS)

Adj. debt to assets ratio $(D E B T)$

Adj. interest to debt ratio $(C O D)$

Log(book value of assets)

Capital expenditure to total assets ratio

$\log (1+$ market value of managerial shares $)$

Tangible assets to assets ratio

Fiscal subsidy to sales ratio

State shareholding

Quick ratio

Secured debt to total debt ratio

Regulated utilities dummy

Conglomerates dummy

Eastern coast dummy

High property risk firms dummy

Hi-tech stock dummy

Operating profit to assets

Domestic public ownership

Foreign ownership

Proportion of independent directors

Unamortized expenses to total assets ratio

SG\&A expense

Operating profit to assets

Firm age (years)

Sales growth ratio

Prime lending rate

Proportion of independent directors

Log of board size

Bank loans to total debt ratio

Interest coverage ratio

No. of Obs.

\begin{tabular}{|c|c|c|c|c|}
\hline $\begin{array}{c}\text { Insurance } \\
\text { Choice } \\
\text { Dummy } \\
\end{array}$ & $\begin{array}{c}\text { Insurance } \\
\text { Disclosure } \\
\text { Dummy }\end{array}$ & $\begin{array}{c}\text { Insurance } \\
\text { to Tangible } \\
\text { Assets } \\
\text { Ratio }\end{array}$ & $\begin{array}{c}\text { Adj. } \\
\text { Debt } \\
\text { to } \\
\text { Assets } \\
\text { Ratio }\end{array}$ & $\begin{array}{c}\text { Adj. } \\
\text { Interest } \\
\text { to Debt } \\
\text { Ratio } \\
\end{array}$ \\
\hline 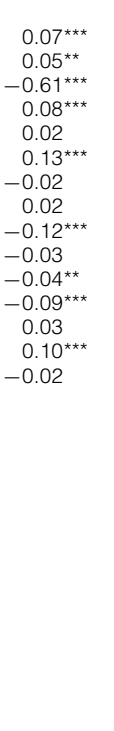 & $\begin{array}{c}-0.07^{\star \star \star} \\
0.03 \\
\\
\\
-0.04^{\star} \\
0.04^{\star} \\
-0.07^{\star \star \star} \\
-0.19^{\star \star \star} \\
0.11^{\star \star \star}\end{array}$ & $\begin{array}{c}-0.04^{\star} \\
0.01 \\
-0.16^{\star \star \star} \\
0.04^{\star} \\
0.01 \\
-0.18^{\star \star *} \\
-0.03 \\
0.02 \\
0.09^{\star \star *} \\
0.02 \\
0.12^{\star \star *} \\
-0.06^{\star *} \\
\\
0.05^{\star *} \\
-0.04^{\star}\end{array}$ & $\begin{array}{r}-0.09^{\star \star \star} \\
0.15^{\star \star \star} \\
0.20^{\star \star \star} \\
-0.09^{\star \star \star} \\
0.06^{\star \star} \\
-0.02\end{array}$ & $\begin{array}{c}0.05^{\star \star} \\
-0.09^{\star \star \star} \\
0.02^{\star} \\
-0.40^{\star \star \star} \\
0.06^{\star \star} \\
0.53^{\star \star \star} \\
-0.10^{\star \star \star}\end{array}$ \\
\hline 2,470 & 2,250 & 2,016 & 2,016 & 2,016 \\
\hline
\end{tabular}

\section{B. Multivariate Analysis}

\section{Results from the Insurance and Disclosure Probit Models}

The results from the insurance and disclosure probit models are reported in Table 4. ${ }^{29}$ Except for the industry dummies of particular interest, the results on other industry dummies are not tabulated in order to save space. First, turning to the results of the insurance probit model, as expected, small firms and firms with more growth opportunities and/or more physical assets-in-place are more likely to insure their assets. The coefficient for fiscal subsidy is negative and significant, implying that the availability of government subsidies reduces com-

\footnotetext{
${ }^{29}$ In estimating the insurance probit model, we treat leverage and the cost of debt as being exogenous to the decision to insure. We believe this assumption should not materially bias our results because prior studies (e.g., Géczy, Minton, and Schrand (1997), Graham and Rogers (2002)) argue that it is not the yes/no decision to hedge that is important but rather it is the amount of hedging that matters. Indeed, Géczy et al. (1997) find no significant impact of the yes/no decision to hedge via derivatives on a firm's debt capacity, whereas Graham and Rogers (2002) report a positive and significant relation between the amount of corporate hedging (using derivatives) and debt capacity.
} 
panies' propensity to purchase commercial insurance. Additionally, the positive and significant coefficient for the regulated utilities dummy is consistent with the argument of Mayers and Smith (1982) that regulated utilities are more likely to use property insurance than less regulated firms. As expected, we find the coefficient of the Eastern coast dummy is positive and significant. This suggests that firms incorporated in China's Eastern coast are more likely to insure their assets than firms incorporated in inland regions.

TABLE 4

Regression Results of the Insurance Probit and the Disclosure Probit

Table 4 shows the regression results from the insurance probit and disclosure probit models. DEBT and COD are industry median-adjusted debt ratio and cost of debt. The insurance probit model is a regression of the insurance choice dummy (1 for carrying property insurance in a given year) on a set of determinants of corporate purchase of property insurance. The disclosure probit model is a regression of the insurance disclosure dummy (1 for disclosing property insurance spending under the "unamortized expenses" item in the annual report) on a set of determinants of voluntary financial disclosure. Five observations are lost due to missing values in the disclosure probit model. ${ }^{\star},{ }^{\star \star},{ }^{\star \star \star}$ are statistically significant at the $0.10,0.05$, and 0.01 levels, respectively. p-values are one-tailed if the coefficient is significant in the hypothesized direction, and two-tailed otherwise.

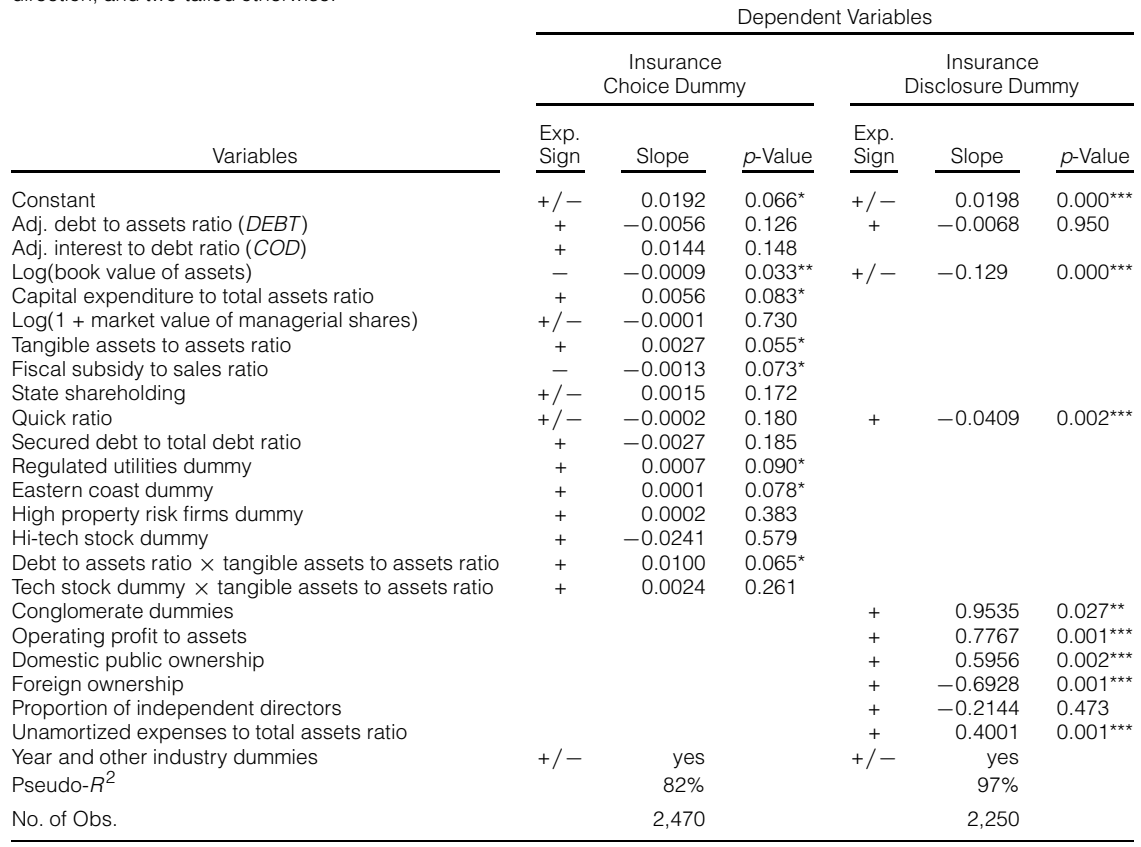

The positive and significant coefficient estimate on the interaction between leverage and tangible assets intensity suggests that for a given level of tangible assets intensity, the propensity to purchase property insurance increases with leverage, or alternatively, for a given level of leverage, the propensity to purchase property insurance increases with tangible assets intensity. Therefore, leverage and tangible assets intensity seem to have a joint effect on the propensity to insure in China. No other variables are found to have important effects on sample firms' incidence of insurance. It is worth noting that the coefficient of secured debt is not significant (which may reflect the noisiness of the proxy; see footnote 
18). The pseudo- $R^{2}$ of the insurance probit model is over $80 \%$ and therefore the model has reasonably good explanatory power.

The voluntary corporate disclosure literature suggests that a firm's financial condition, ownership structure, board composition, and industry membership could have important impacts on the comprehensiveness of its voluntary disclosures (e.g., see Wallace and Naser (1995), Chen and Jaggi (2000)). For example, firms with a high debt ratio, a high liquidity ratio, or strong profitability are likely to disclose more fully than other firms. This is because firms with a high debt ratio may face increased demands for greater information disclosure from creditors, while firms with a high liquidity ratio may choose to disclose more information to outsiders in order to signal their financial strength. Managers of firms with good financial performance may wish to provide more detailed disclosures to assure investors of the prospects for future profitability and in the expectation of improving their compensation packages. Furthermore, Chinese firms with more public and foreign ownership and/or more independent directors are likely to disclose more information to reduce information asymmetry and/or lower the costs of future equity issues. Conglomerates tend to have greater business complexity and therefore are likely to disclose more information externally than other firms. However, the linkage between firm size and the comprehensiveness of its disclosure is less clear. For example, on the one hand, large firms may opt to disclose less information in order to avoid increased political/regulatory scrutiny; on the other hand, they may disclose more details because they have more stakeholders demanding information. We also expect that firms with more unamortized expenses are more likely to itemize property insurance spending and other expense items in the annual report-a financial reporting requirement in China.

Five observations are lost due to missing values in ownership variables in the disclosure probit model. The results from estimating our disclosure probit model show that, as we expected, conglomerates and firms with strong profitability, more unamortized expenses, and/or more domestic public ownership are more likely to disclose property insurance spending in annual reports than other firms. Also, small firms and firms with a low quick ratio and/or less foreign ownership are more likely to disclose property insurance spending than other firms. This is plausible because small firms tend to proportionately buy more property insurance than their large firm counterparts (Zou et al. (2003)). Additionally, firms with a low quick ratio may face a high cost of debt and so may have to provide lenders with information relating to potential risks on their insured collateral. The pseudo$R^{2}$ is over $95 \%$, indicating a good fit for the disclosure probit model.

\section{Basic Results from the System of Simultaneous Equations}

Before introducing our estimation procedures, it is useful to check whether our system of simultaneous equations is identified. Following the order condition rule in all three equations, the number of (endogenous and exogenous) variables missing from each equation is greater than 2 (the total number of endogenous variables 3 minus 1) (see Kennedy (1998), p. 160). Therefore, each equation and hence the system can be identified.

Equations (1), (2), and (3) are estimated using two-stage least squares (2SLS). In the first stage, the endogenous variables $I N S, D E B T$, and $C O D$ are regressed 
on all the exogenous variables in the three equations, plus the industry and year dummies, respectively. The predicted value from each regression is then used as the instrument for $I N S, D E B T$, and $C O D$, respectively. In the second stage, equations (1), (2), and (3) are estimated using the instruments for the endogenous variables and the other (exogenous) variables in the equation. We employ the Newey-West (1987) heteroskedasticity and autocorrelation consistent (HAC) standard errors, as our tests indicate the existence of heteroskedasticity and autocorrelation (Greene (2000)).

\section{a. Main Results}

Table 5, Model 1 reports the results from the second-stage three-equation models. In equation (1), the coefficient on the predicted $D E B T$ is negative and statistically significant. This is consistent with the finding of Zou and Adams (2006) that high leverage does not lead Chinese PLCs to buy more property insurance, but runs contrary to the evidence obtained from the U.S. (e.g., see Hoyt and Khang (2000)). One reason may be that in China SOEs are rarely bankrupted due to governmental concerns about maintaining public welfare and social stability. While there are indirect costs of financial distress, such costs seem not to be high enough to motivate the managers of firms with high leverage to increase their property insurance coverage. Consistent with our expectations, the coefficient on the predicted $C O D$ is positive and statistically significant, implying that a high cost of debt may motivate Chinese managers to increase their levels of property insurance coverage.

In equation (2), where the dependent variable is $D E B T$, the coefficient on the predicted INS is positive and highly significant. This suggests that property insurance coverage can help facilitate borrowing and thereby expand the insuring firm's debt capacity (since the credit risk facing the lender is reduced by property insurance coverage). To our knowledge, this is the first evidence in the literature showing that property insurance helps expand corporate debt capacity. On average, a one basis point increase in property insurance spending (relative to the book value of tangible assets) tends to increase the (industry median-adjusted) debt to assets ratio by $0.2 \%$. Also as expected, the coefficient on the predicted $C O D$ is negative and statistically significant. Therefore, firms with high interest costs tend to use less debt.

Turning to the results of equation (3), which uses $C O D$ as the dependent variable, the coefficient on the predicted INS is, as predicted, negative and statistically significant at the 0.10 level (one-tailed). Therefore, property insurance appears to help lower the cost of debt. On average, a one basis point increase in property insurance spending (relative to the book value of tangible assets) tends to lower the (industry median-adjusted) interest to debt ratio by about one basis point. ${ }^{30}$ To assess the magnitude of the associated economic benefits, we consider a firm with average asset size and capital structure, where a one basis point decrease in the interest rate translates into an annual interest saving of about RMB

\footnotetext{
${ }^{30}$ The result, however, should be treated with caution as the empirical relation between the extent of property insurance and the cost of debt may not be strictly linear. For example, property insurance coverage may be capped at the market value or actual cash cost of the assets insured. Likewise, a firm may not be able to lower its cost proportionately, given that lenders are looking for a minimum required rate of return on loan business.
} 


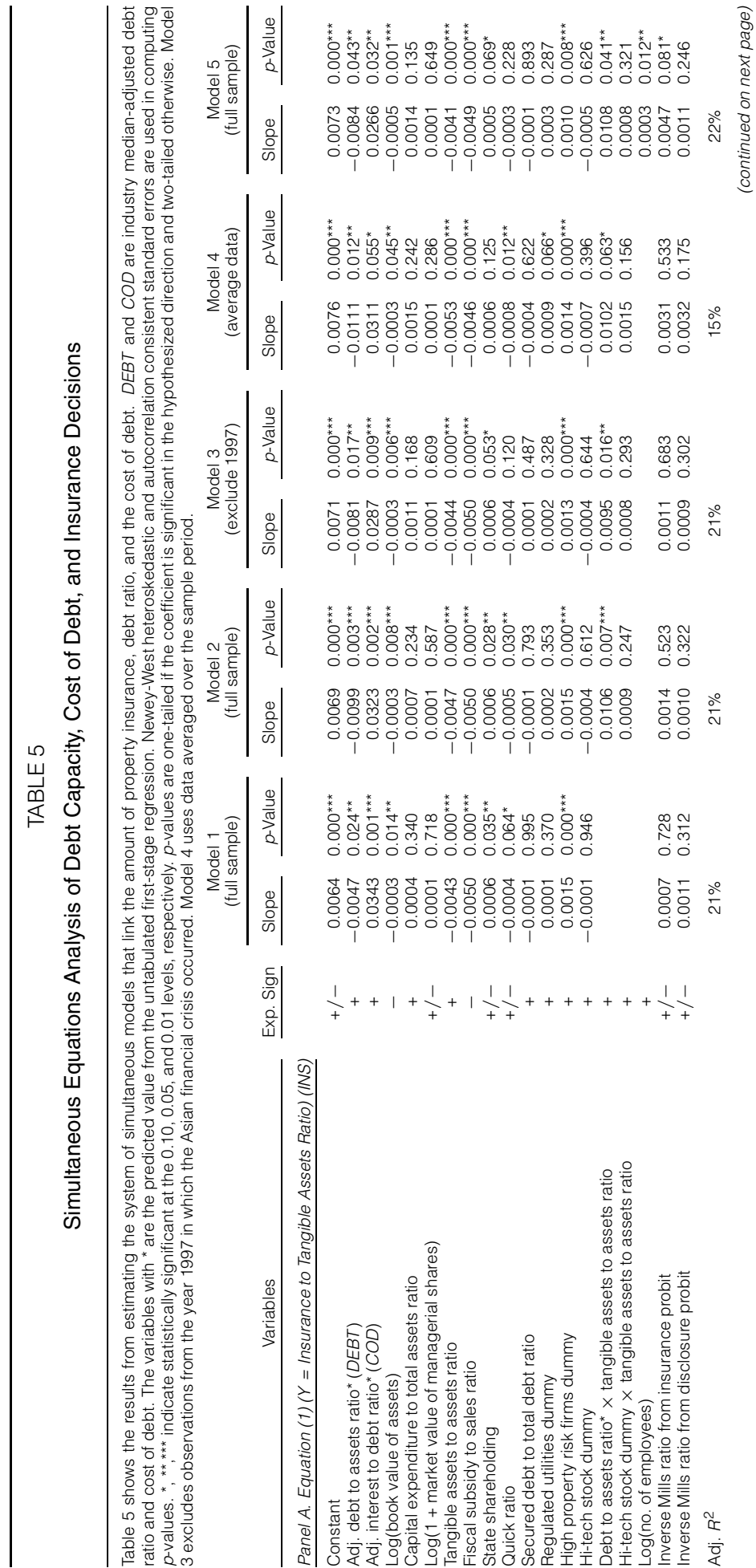




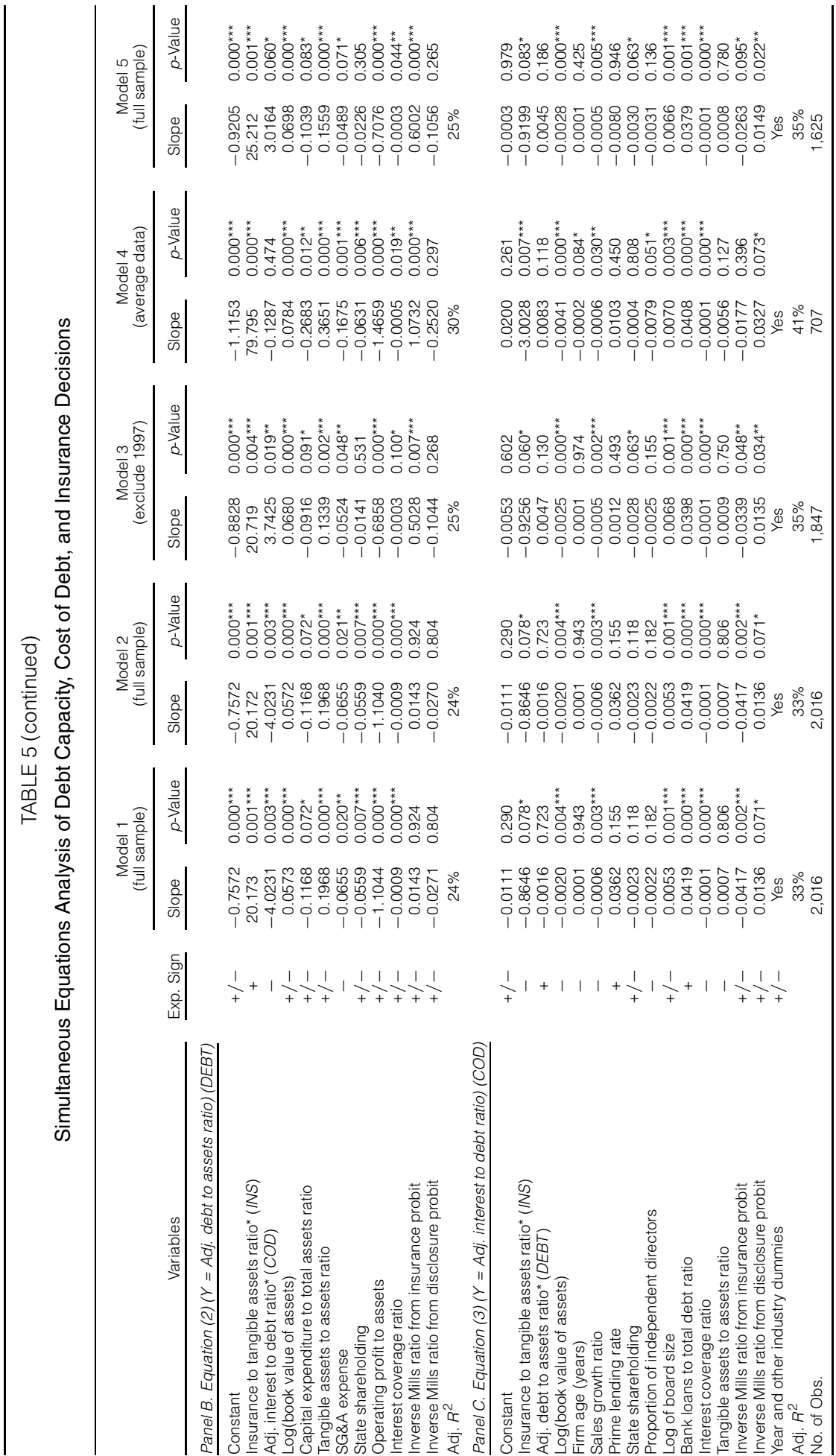


0.056 million. ${ }^{31}$ To our knowledge, this is the first direct evidence on the role of property insurance in lowering corporate borrowing costs. The coefficient on predicted $D E B T$ is not significant in the cost of debt equation.

\section{b. Results on the Interaction Terms}

In Model 1 of Table 5, we find that leverage is negatively correlated with the amount of property insurance and the hi-tech stock dummy has no effect on the amount of property insurance. As discussed previously, the relation between these two variables and the purchase of property insurance may be conditioned on the amount of tangible assets. Model 2 tests this possibility by including leverage $\times$ tangible assets intensity and hi-tech stock dummy $\times$ tangible assets intensity. After controlling for the interaction terms, leverage remains negatively correlated with the amount of property insurance and the hi-tech stock dummy remains statistically insignificant. The coefficient for leverage $\times$ tangible assets intensity is, as predicted by $\mathrm{H} 1 \mathrm{~b}$, positive and statistically significant. This suggests that for a given level of tangible assets intensity, the purchase of property insurance increases with leverage, or alternatively, for a given level of leverage, the purchase of property insurance increases with tangible assets intensity. Therefore, leverage and tangible assets intensity seem to have a joint effect on the purchase of property insurance in China. Albeit with a positive sign, the coefficient for hi-tech stock dummy $\times$ tangible assets intensity is not statistically significant. Our other results are qualitatively similar to those of Model 1.

\section{c. Results on Control Variables}

Our following discussion is based on the results from Model 2 of Table 5. Consistent with the extant literature (e.g., Mayers and Smith (1990), Zou et al. (2003), and Zou and Adams (2006)), small companies are found to insure relatively more of their tangible assets than large companies. Also, as expected, firms with more government fiscal subsidies tend to buy less property insurance, thereby supporting the predicted negative relation between fiscal subsidies and the use of commercial insurance. However, at variance with what we hypothesized, but consistent with the findings of Zou and Adams (2006), we find that Chinese firms with a higher proportion of tangible assets tend to buy less property insurance than firms with lower tangible assets intensity. It is possible that firms with more tangible assets-in-place can effectively diversify the risk of their collateral being impaired by unanticipated future loss events by offering lenders other tangible assets as surety for loans granted. Therefore, firms with a higher proportion of tangible assets may have less need for property.

The negative coefficient on the quick ratio runs contrary to the financial constraints argument, but could reflect that firms with a low quick ratio may face a high cost of debt and need to provide insured collateral to be able to borrow. Alternatively, firms with a low quick ratio are more risky and need to use insurance on tangible assets as a contingent financing mechanism. As expected, compa-

\footnotetext{
${ }^{31}$ The average $\log$ asset value (size) for our sample firms reporting property insurance spending is 11.71; this translates into a total book worth of RMB 1,217.8 million. Applying the sample's average debt ratio of $46.2 \%$, a typical sample firm on average has RMB 562.6 million of total debt. A one basis point decrease in interest rate from increasing insurance by one basis point of the amount of tangible assets means that roughly RMB 0.056 million of annual interest can be saved.
} 
nies prone to accidental property damage (e.g., oil and gas companies) tend to purchase more property insurance than other firms, but the hi-tech stock dummy does not appear to affect the purchase of property insurance. Additionally, as in Graham and Rogers (2002), we do not find firms with more capital expenditure tend to engage in more risk management (via purchasing property insurance) - a feature that could reflect cash flow shortages in such firms. It is also plausible that new tangible assets could help diversify the risk of collateral damage and thereby lower the need for property insurance.

It is worth noting that the coefficient on State shareholding is positive and significant. Therefore, firms with a higher level of State ownership appear to insure more than firms with a low level of State shareholdings. This finding provides some support for the political incentive hypothesis. We find no other variables having significant coefficients in the regression. ${ }^{32}$

On the other determinants of the debt to assets ratio, while neither the static trade-off model nor the $\mathrm{POH}$ is fully supported by our results, the trade-off model appears to gain more relevance. Specifically, consistent with the static trade-off model, large firms and firms with more tangible assets, less non-debt tax shields, and/or less growth opportunities tend to use more debt than other firms. In contrast, the negative and significant coefficient on the ratio of operating profit to total assets conforms to the prediction of the $\mathrm{POH}$. These findings also are consistent with the evidence from several prior studies (e.g., Chen (2004), Zou and Xiao (2006)) on the determinants of capital structure of listed companies in China.

The negative and significant coefficient of the interest coverage ratio in equation (2) may imply that firms with adequate interest coverage could be profitable and more likely to secure financing via retained profit rather than borrowing. Indeed, we find firms with strong profitability tend to have low leverage. Alternatively, profitable firms are able to issue shares to raise capital under the Chinese equity issuance controls that impose minimum profitability requirements. Furthermore, the coefficient of State ownership is negative and significant, indicating that firms with a high level of State ownership tend to have lower leverage. This finding is consistent with the argument that firms with a high level of State ownership tend to have better access to stock market finance.

The results on the other determinants of the interest to debt ratio are generally consistent with our theoretical predictions. Specifically, large firms and firms with high sales growth rates, and/or an adequate interest coverage ratio tend to enjoy lower rates of interest. Firms with large boards are found to have a higher borrowing cost, which may be explained by Yermack's (1996) view that large boards reduce firms' financial performance and thereby increase borrowing costs. Anderson et al. (2004) rely on the assumption that a large board is more effective than a small board in improving the quality of financial statements and thereby helps lower the cost of debt. However, in China, a large corporate board (which is

\footnotetext{
${ }^{32}$ The result on managerial ownership is different from Zou and Adams (2006) (using a sample of 235 Chinese firms for the period 1997 through 1999) in that they report a positive and significant coefficient. In addition to the cross-sectional/time-series differences between their study and ours, one possible reason might be that in 2001 the CSRC abolished the practice of offering new shares to company managers at the time of an IPO. As a result, managers often have to buy company shares (if they wish) from the secondary market at a much higher price than the IPO price. This may weaken the effect of managerial shareholdings on the property insurance decision.
} 
often dominated by executive directors and/or representatives of large shareholders) may not lead to stronger independence and greater strategic and operational effectiveness. Finally, Chinese firms' borrowing costs are found to increase with the proportion of debt from bank loans. This suggests that in China bank loans are more expensive to use than other forms of debt, which may operate in a more competitive environment.

\section{Robustness Checks}

In this section, we conduct several robustness checks to examine the sensitivity of our results. Importantly, our major results survive these further tests.

\section{Effect of the Asian Financial Crisis}

The Asian financial crisis occurred in 1997 and so it is interesting to see whether our major results are confounded by this crisis. We run a model using a sample without the 169 observations from 1997. Our major results reported under Model 3 in Table 5 are qualitatively similar despite changes in the coefficients of some control variables (e.g., the quick ratio in equation (1) and State ownership in equation (3)). As another check, we define a year-break dummy variable that takes 1 for years 1997 through 2000 and 0 for years 2001 through 2003. We then include this dummy and its interactions with each of the predicted values of our three endogenous variables (derived from the first-stage OLS regressions) in the second-stage regressions. We reestimate Model 2 of Table 5 and in unreported results, ${ }^{33}$ the year-break dummy and the interactions with the three endogenous variables are not statistically significant and our major findings remain unchanged. Therefore, there is no evidence that our major results are confounded by the Asian financial crisis.

\section{Average Regression}

As our sample is a pooled time-series and cross-sectional dataset, we also conduct regressions using data averaged over the sample period. However, one caveat in using average data is that it may cause a loss of some useful information. The results reported in Model 4 of Table 5 show that our major results on the leverage-insurance relation and the cost of debt-insurance relation still hold. One difference is that the estimate of the coefficient of INS is now negative and highly significant in the cost of debt model (i.e., equation (3)), while it is only marginally significant in the pooled analysis.

\section{Additional Control Variable}

We include the natural logarithm of the number of employees as a further control variable in the insurance model (i.e., equation (1)). This is because in China the issue of employment and job protection may prompt politically connected company managers to purchase property insurance. As many Chinese firms did not disclose such data item in 1997 and 1998, the sample size is significantly reduced. However, such a reduced sample serves as another opportunity to

\footnotetext{
${ }^{33}$ Unreported results are available from the authors.
} 
examine the tenor of our major findings. In unreported results from the insurance probit model, the coefficient on the employee variable is positive and significant ( $p$-value $=0.06$, one-tailed). The results from the simultaneous equation analysis are reported under Model 5 of Table 5. The coefficient estimate of the employee variable in the insurance equation is positive and significant. These results support the view that in China, employment and job protection may be a factor affecting the corporate purchase of property insurance. However, our major findings on the three endogenous variables are unaffected.

Our sample comprises firms listed only in domestic stock exchanges and firms whose shares are traded in both domestic and overseas exchanges (e.g., Hong Kong). The latter firms have better access to equity financing and are subject to a higher standard of monitoring and more stringent mandatory disclosure rules that may help to increase their debt capacity. We include in the debt equation a dummy variable DUALLIST taking 1 for overseas listing status and rerun Models 1-5 of Table 5. In unreported results, the estimated coefficient of DUALLIST ranges from 0.126 to 0.142 and is consistently significant at the 0.01 level (twotailed). This result supports the view that, other things being equal, firms listed in more established overseas stock exchanges tend to have a greater debt capacity (on average about $13 \%$ higher) than firms that are only listed in domestic stock exchanges. However, there is little change in the results for the other variables.

\section{Other Tests}

As a further check, we estimated the system of simultaneous equations using the three-stage least squares (3SLS) regression. The 3SLS regression estimation is a "full information" method that utilizes all the zero restrictions in the system instead of estimating the structural parameters of each equation separately. However, Newey-West heteroskedastic and autocorrelation consistent standard errors are not available for the 3SLS estimation; in contrast, the 2SLS estimator is shown to be quite robust to heteroskedasticity and specification errors (see Kennedy (1998), p. 165). As such, we place more weights on the 2 SLS results. In unreported results, in addition to the previous findings that a high cost of debt leads to more insurance purchases and insurance purchases help expand debt capacity and reduce the cost of debt, we also find the coefficient of leverage is positive and significant in the insurance model, but the coefficient of the interaction term between leverage and tangible assets ratio is unexpectedly negative and significant. We place less weight on the latter findings due to the econometric issues with 3SLS.

Finally, we excluded observations with values over the 99.5 percentile of the cost of debt, interest coverage ratio, or SG\&A expense rather than winsorize the observations. We repeated the analysis of Models 1-5 and our major findings are not changed by this treatment.

In Models 1-5, the coefficients for the inverse Mills ratios are generally insignificant in the insurance model, while the coefficient for the inverse Mills ratio from the insurance probit model is positive and significant in some of the leverage models. This suggests that the unobserved factors that may prompt firms to insure their assets tend to be positively correlated with leverage. In contrast, the coefficient of the inverse Mills ratio from the insurance probit model is generally 
negative and significant in the cost of debt model, implying that the unobserved factors that prompt firms to insure their assets tend to be negatively correlated with the cost of debt. We also find the coefficient of the inverse Mills ratio from the insurance disclosure probit model is generally positive and significant in the cost of debt model. Therefore, the unobserved factors that induce firms to disclose their property insurance in annual reports tend to be positively correlated with the cost of debt.

\section{Conclusion}

This study extends the corporate risk management literature in two key regards. First, we test whether corporate risk management expands debt capacity within the context of property insurance. Second, we focus more broadly on the linkage between commonly used property insurance and the overall cost of borrowing.

Our results suggest that in China, a high cost of debt appears to induce the corporate use of property insurance, but high leverage alone does not lead to the purchase of property insurance. The latter finding might reflect the unique institutional setting of China-for example, the cost of financial distress might be lower than in the West. We observe that leverage and tangible assets intensity seem to exert a positive joint effect on the corporate purchase of property insurance. On the effect of insurance, we find evidence supporting the contention that property insurance helps expand insuring firms' debt capacity and helps lower their borrowing costs. However, the limited evidence on the cost reduction effect suggests that lowering the borrowing cost is likely to be a concern secondary to facilitating corporate borrowings and thereby expanding debt capacity in corporate property insurance decisions in China. Indeed, buying insurance can still be optimal even when the savings in the cost of debt do not exceed the insurance premium given many other benefits of insurance (e.g., expanded debt capacity, reduced bankruptcy risk, and financial distress costs).

Finally, our evidence on the role of property insurance in expanding debt capacity complements Graham and Rogers' (2002) study on financial derivatives hedging in the U.S. corporate sector. The evidence that property insurance helps lower the cost of debt extends the results of prior studies (i.e., Cole and Officer (1981), Kidwell et al. (1987)) on the interest cost advantages of purchasing financial guarantee insurance. Therefore, taken together, debt capacity, the cost of debt, and corporate property insurance appear to be simultaneously related. We believe that future studies should use datasets from developed economies to assess the generality of our results. 
APPENDIX

Variable Definitions and Data Sources

\begin{tabular}{|c|c|c|}
\hline Variables & Definition & Data Source \\
\hline $\begin{array}{l}\text { 1. Insurance choice } \\
\text { dummy }\end{array}$ & $\begin{array}{l}1 \text { = carrying property insurance in a } \\
\text { firm/year and } 0 \text { for otherwise. }\end{array}$ & $\begin{array}{l}\text { Annual report search, survey and } 75 \\
\text { non-insurance observations from Zou and } \\
\text { Adams (2006) }\end{array}$ \\
\hline
\end{tabular}

2. $\log$ (book value of assets)

3. Debt to assets ratio

4. Interest to debt ratio

5. Tangible assets to assets ratio

6. Capital expenditure to total assets ratio

7. $\log (1+$ market value of managerial shares)

8. Fiscal subsidy to sales ratio

9. Proportion of State shareholdings

10. Quick ratio

11. Secured debt to total debt ratio

12. Insurance disclosure dummy

13. Operating profit to assets ratio

14. Domestic public ownership

15. Foreign ownership

16. Proportion of independent directors

17. Unamortized expenses to total assets ratio

18. Insurance-to-tangible assets ratio

19. SG\&A expense

20. Firm age (years)

21. Sales growth ratio

22. Prime lending rate

23. Log of board size

24. Bank loans to total debt ratio
Natural logarithm of book values of total assets (in 10,000 RMB).

Total liabilities $\div$ total assets.

(Interest charges in the profit and loss account + interest capitalized in the current year in balance sheet $) \div$ total liabilities

(Fixed assets + inventory) $\div$ total assets.

Annual expenditure in acquiring new fixed assets and intangible assets $\div$ total assets.

Natural logarithm of $(1+$ total number of managerial shareholdings $\times$ monthly average A-share price in the year concerned) (market value is in RMB).

Total annual subsidies received from the government $\div$ total sales income

Total number of State-held shares $\div$ total shares outstanding.

(Current assets - inventory) $\div$ current liabilities.

Total amount of secured bank loans and other debt $\div$ total liabilities.

1 = a firm/year disclosed property insurance Search of annual reports spending in the annual report.

Operating profit $\div$ the prior year-end total assets.

(Number of tradable A-shares $\div$ total shares CSMAR database outstanding.)

(Number of foreign-founder shares + number of domestically traded B-shares + number of overseas traded $\mathrm{H}$-shares) $\div$ total shares outstanding.

Number of independent directors $\div$ board size.

Amount of unamortized expenses $\div$ tota assets.

Property insurance spending $\div$ the prior year-end value of fixed assets and inventor

Sales expenses, general and administrative expenses (including depreciation but excluding interest) $\div$ sales income.

Number of years since incorporation.

Current sales income $\div$ last year's sales income.

The 1-3 year interest rate of bank loans set from the PBOC's official website by the People's Bank of China (PBOC).

Natural log of total number of board directors CSMAR database

(Short-term bank borrowing + long-term bank borrowing) $\div$ total liabilities.
CSMAR database

CSMAR database

\section{CSMAR database}

\section{CSMAR database}

Interest data are from WIND system or

CSMAR database

\section{CSMAR database}

Shareholdings data are collected from annual reports; monthly share price data are from DataStream database

CSMAR database

CSMAR database

\section{CSMAR database}

Secured debt is hand-collected from annual reports

CSMAR database

CSMAR database

CSMAR database

Insurance data are collected from annual reports

CSMAR database

\section{CSMAR database}

CSMAR database

(continued on next page) 
APPENDIX (continued)

Variable Definitions and Data Sources

\begin{tabular}{|c|c|c|c|}
\hline & Variables & Definition & Data Source \\
\hline 25. & Interest coverage ratio & $\begin{array}{l}\text { Earnings before interest, tax, and } \\
\text { extraordinary items } \div \text { (interest charges in } \\
\text { the profit and loss account }+ \text { interest } \\
\text { capitalized in the current year in the balance } \\
\text { sheet). }\end{array}$ & $\begin{array}{l}\text { Earnings are from CSMAR database; intere } \\
\text { data are from WIND system or collected } \\
\text { from annual reports }\end{array}$ \\
\hline 26. & $\begin{array}{l}\text { Industry dummy } 1 \\
\text { (regulated utilities) }\end{array}$ & $\begin{array}{l}\text { For regulated electric, gas, and sanitary } \\
\text { service firms. }\end{array}$ & $\begin{array}{l}\text { The } 2001 \text { CSRC Industry Classification-B } \\
\text { code = DO }\end{array}$ \\
\hline 27. & $\begin{array}{l}\text { Industry dummy } 2 \\
\text { (high property risk } \\
\text { firms dummy) }\end{array}$ & $\begin{array}{l}\text { For firms manufacturing chemicals, plastics } \\
\text { and rubber, oil and gas exploration \& } \\
\text { refining, coal mining or metallurgical } \\
\text { engineering firms. }\end{array}$ & $\begin{array}{l}\text { The 2001 CSRC Industry Classification-B } \\
\text { code = B0; C4; C6 }\end{array}$ \\
\hline 28. & $\begin{array}{l}\text { Industry dummy } 3 \\
\text { (high-tech stock } \\
\text { dummy) }\end{array}$ & $\begin{array}{l}\text { For Internet stock, firms manufacturing } \\
\text { computer software and hardware, } \\
\text { communications equipment, } \\
\text { pharmaceuticals and bio-tech firms. }\end{array}$ & $\begin{array}{l}\text { The } 2001 \text { CSRC Industry Classification-B } \\
\text { code = C8; G8; L1 }\end{array}$ \\
\hline 29. & Industry dummy 4 & $\begin{array}{l}\text { For firms engaging in agriculture, forestry, or } \\
\text { fishing. }\end{array}$ & $\begin{array}{l}\text { The } 2001 \text { CSRC Industry Classification-B } \\
\text { code }=\text { AO }\end{array}$ \\
\hline 30. & Industry dummy 5 & $\begin{array}{l}\text { For firms engaging in metal mining, coal } \\
\text { mining, or oil \& gas extraction. }\end{array}$ & $\begin{array}{l}\text { The } 2001 \text { CSRC Industry Classification-B } \\
\text { code = B0 }\end{array}$ \\
\hline 31. & Industry dummy 6 & $\begin{array}{l}\text { For firms engaging in foodstuff or beverage } \\
\text { production. }\end{array}$ & $\begin{array}{l}\text { The } 2001 \text { CSRC Industry Classification-B } \\
\text { code }=\text { CO }\end{array}$ \\
\hline 32. & Industry dummy 7 & $\begin{array}{l}\text { For firms engaging in textile products or } \\
\text { apparel manufacturing. }\end{array}$ & $\begin{array}{l}\text { The } 2001 \text { CSRC Industry Classification-B } \\
\text { code = C1 }\end{array}$ \\
\hline 33. & Industry dummy 8 & $\begin{array}{l}\text { For firms engaging in furniture and fixture } \\
\text { manufacturing. }\end{array}$ & $\begin{array}{l}\text { The } 2001 \text { CSRC Industry Classification-B } \\
\text { code = C2 }\end{array}$ \\
\hline 34. & Industry dummy 9 & $\begin{array}{l}\text { For firms engaging in paper and allied } \\
\text { products manufacturing. }\end{array}$ & $\begin{array}{l}\text { The } 2001 \text { CSRC Industry Classification-B } \\
\text { code = C } 3\end{array}$ \\
\hline 35. & Industry dummy 10 & $\begin{array}{l}\text { For firms engaging in petroleum refining, } \\
\text { chemicals, rubbers or plastics production. }\end{array}$ & $\begin{array}{l}\text { The } 2001 \text { CSRC Industry Classification-B } \\
\text { code }=\text { C4 }\end{array}$ \\
\hline 36. & Industry dummy 11 & $\begin{array}{l}\text { For firms engaging in electronic equipment } \\
\text { and components (except computer). }\end{array}$ & $\begin{array}{l}\text { The } 2001 \text { CSRC Industry Classification-B } \\
\text { code }=\text { C5 }\end{array}$ \\
\hline 37. & Industry dummy 12 & For firms in primary metal industry. & $\begin{array}{l}\text { The } 2001 \text { CSRC Industry Classification-B } \\
\text { code = C6 }\end{array}$ \\
\hline 38. & Industry dummy 13 & $\begin{array}{l}\text { For firms engaging in industrial machinery or } \\
\text { transportation equipment manufacturing. }\end{array}$ & $\begin{array}{l}\text { The } 2001 \text { CSRC Industry Classification-B } \\
\text { code }=\text { C7 }\end{array}$ \\
\hline 39. & Industry dummy 14 & For pharmaceutical or bio-tech firms. & $\begin{array}{l}\text { The } 2001 \text { CSRC Industry Classification-B } \\
\text { code }=\text { C } 8\end{array}$ \\
\hline 40. & Industry dummy 15 & For miscellaneous manufacturing industry. & $\begin{array}{l}\text { The } 2001 \text { CSRC Industry Classification-B } \\
\text { code }=\text { C9 }\end{array}$ \\
\hline 41. & Industry dummy 16 & For construction firms. & $\begin{array}{l}\text { The } 2001 \text { CSRC Industry Classification-B } \\
\text { code = EO }\end{array}$ \\
\hline 42. & Industry dummy 17 & For transportation firms. & $\begin{array}{l}\text { The } 2001 \text { CSRC Industry Classification-B } \\
\text { code = FO }\end{array}$ \\
\hline 43. & Industry dummy 18 & For warehousing firms. & $\begin{array}{l}\text { The } 2001 \text { CSRC Industry Classification-B } \\
\text { code = F2 }\end{array}$ \\
\hline
\end{tabular}




\begin{tabular}{|c|c|c|}
\hline \multicolumn{3}{|c|}{ APPENDIX (continued) } \\
\hline \multicolumn{3}{|c|}{ Variable Definitions and Data Sources } \\
\hline Variables & Definition & Data Source \\
\hline 44. Industry dummy 19 & $\begin{array}{l}\text { For firms engaging in communication } \\
\text { equipment or computer manufacturing. }\end{array}$ & $\begin{array}{l}\text { The } 2001 \text { CSRC Industry Classification-B } \\
\text { code = G8 }\end{array}$ \\
\hline 45. Industry dummy 20 & For wholesale trading firms. & $\begin{array}{l}\text { The } 2001 \text { CSRC Industry Classification-B } \\
\text { code }=\mathrm{H} 0\end{array}$ \\
\hline 46. Industry dummy 21 & For retail trading firms. & $\begin{array}{l}\text { The } 2001 \text { CSRC Industry Classification-B } \\
\text { code }=\mathrm{H} 1\end{array}$ \\
\hline 47. Industry dummy 22 & $\begin{array}{l}\text { For real estate firms and property } \\
\text { developers. }\end{array}$ & $\begin{array}{l}\text { The } 2001 \text { CSRC Industry Classification-B } \\
\text { code = J0 }\end{array}$ \\
\hline 48. Industry dummy 23 & $\begin{array}{l}\text { For firms engaging in hotel and lodging } \\
\text { business. }\end{array}$ & $\begin{array}{l}\text { The } 2001 \text { CSRC Industry Classification-B } \\
\text { code }=\text { K3 }\end{array}$ \\
\hline 49. Industry dummy 24 & For software and Internet firms. & $\begin{array}{l}\text { The } 2001 \text { CSRC Industry Classification-B } \\
\text { code }=\text { L1 }\end{array}$ \\
\hline $\begin{array}{l}\text { 50. Industry dummy } 25 \\
\text { (conglomerates) }\end{array}$ & For conglomerates. & $\begin{array}{l}\text { The } 2001 \text { CSRC Industry Classification-B } \\
\text { code }=\mathrm{M}\end{array}$ \\
\hline 51. Eastern coast dummy & $\begin{array}{l}1 \text { for firms from China's Eastern coast and } 0 \\
\text { for firms incorporated in inland areas. }\end{array}$ & CSMAR database \\
\hline
\end{tabular}

All variables are measured over the period 1997 through 2003. Industry dummies 10, 14, and 19 are omitted from regression due to industry dummy 10's high correlation with the high property risk firms dummy and industry dummies 14 and 19's high correlation with the high-tech stock dummy.

\section{References}

Allayannis, G., and E. Ofek. "Exchange Rate Exposure, Hedging, and the Use of Foreign Currency Derivatives." Journal of International Money and Finance, 20 (2001), 273-296.

Anderson, R. C.; S. A. Mansi; and D. M. Reeb. "Board Characteristics, Accounting Report Integrity and the Cost of Debt." Journal of Accounting and Economics, 37 (2004), 315-342.

Barton, J. "Does the Use of Financial Derivatives Affect Earnings Management Decisions?" Accounting Review, 76 (2001), 1-26.

Booth, L.; V. Aivazian; A. Demirguc-Kunt; and V. Maksimovic. "Capital Structures in Developing Countries." Journal of Finance, 56 (2001), 87-130.

Bradley, M.; G. Jarrell; and E. H. Kim. "On the Existence of an Optimal Capital Structure: Theory and Evidence." Journal of Finance, 39 (1984), 857-878.

Chen, C. J. P., and B. Jaggi. "Association between Independent Non-Executive Directors, Family Control and Financial Disclosures in Hong Kong." Journal of Accounting and Public Policy, 19 (2000), 285-310.

Chen, J. "Determinants of Capital Structure of Chinese-listed Companies." Journal of Business Research, 57 (2004), 1341-1351.

Chen, K. C. W., and H. Yuan. "Earnings Management and Capital Resource Allocation: Evidence from China's Accounting-Based Regulation of Rights Issues." Accounting Review, 79 (2004), 645-665.

China Securities Regulatory Commission (CSRC) Database. Beijing: CSRC (2000).

Cole, C. W., and D. T. Officer. "The Interest Cost Effect of Private Municipal Bond Insurance." Journal of Risk and Insurance, 48 (1981), 435-449.

Diamond, D. W. "Financial Intermediation and Delegated Monitoring." Review of Economic Studies, 51 (1984), 393-414.

Fama, E. F., and K. R. French. "Testing Trade-off and Pecking Order Predictions about Dividends and Debt." Review of Financial Studies, 15 (2002), 1-33.

Firth, M.; P. M. Y. Fung; and O. M. Rui. "Firm Performance, Governance Structure, and Top Management Turnover in a Transitional Economy.” Working Paper, Hong Kong Polytechnic University (2002). 
Frank, M. Z., and V. K. Goyal. "Testing the Pecking Order Theory of Capital Structure.” Journal of Financial Economics, 67 (2003), 217-248.

Froot, K. A.; D. S. Scharfstein; and J. C. Stein. "Risk Management: Coordinating Corporate Investment and Financing Policies." Journal of Finance, 48 (1993), 1629-1658.

Géczy, C.; B. A. Minton; and C. Schrand. "Why Firms Use Currency Derivatives." Journal of Finance, 52 (1997), 1323-1354.

Goldman Sachs. "Capital Markets Transforming China." People's Daily, overseas edition, June 30, 2001, p. 7.

Grace, M. F., and M. J. Rebello. "Financing and the Demand for Corporate Insurance." Geneva Papers on Risk and Insurance Theory, 18 (1993), 147-172.

Graham, J. R. "Proxies for the Corporate Marginal Tax Rate." Journal of Financial Economics, 42 (1996), 187-221.

Graham, J. R., and D. A. Rogers. "Do Firms Hedge in Response to Tax Incentives?" Journal of Finance, 57 (2002), 815-838.

Greene, W. H. Econometric Analysis. Englewood Cliffs, NJ: Prentice-Hall (2000).

Grillet, L. "Corporate Insurance and Corporate Stakeholders: Transaction Costs Theory." Journal of Insurance Regulation, 11 (1992), 233-251.

Guay, W. R. "The Impact of Derivatives on Firm Risk: An Empirical Examination of New Derivative Users." Journal of Accounting and Economics, 26 (1999), 319-351.

Guedes, J., and T. Opler. "The Determinants of the Maturity of Corporate Debt Issues." Journal of Finance, 51 (1996), 1809-1833.

Gul, F. A. "Government Share Ownership, Investment Opportunity Set and Corporate Policy Choices in China." Pacific-Basin Finance Journal, 7 (1999), 157-172.

Hall, B., and K. Murphy. "Stock Options for Undiversified Executives." Journal of Accounting and Economics, 33 (2002), 3-42.

Haushalter, G. D. "Financing Policy, Basis Risk, and Corporate Hedging: Evidence from Oil and Gas Producers." Journal of Finance, 55 (2000), 107-151.

Healy, P. M., and K. G. Palepu. "Information Asymmetry, Corporate Disclosure, and the Capital Market: A Review of the Empirical Disclosure Literature." Journal of Accounting and Economics, 31 (2001), 485-520.

Hoyt, R. E., and H. Khang. "On the Demand for Corporate Property Insurance." Journal of Risk and Insurance, 67 (2000), 91-107.

Huberman, G. "Corporate Risk Management to Reduce Borrowing Costs." Economics Letters, 54 (1997), 265-269.

Jensen, M. C., and W. H. Meckling. "Theory of the Firm: Managerial Behavior, Agency Costs and Ownership Structure.” Journal of Financial Economics, 3 (1976), 305-360.

Johnson, S. A. "An Empirical Analysis of the Determinants of Corporate Debt Ownership Structure." Journal of Financial and Quantitative Analysis, 32 (1997), 47-69.

Jun, S.-G., and F. C. Jen. "Trade-off Model of Debt Maturity Structure." Review of Quantitative Finance and Accounting, 20 (2003), 5-34.

Kennedy, P. A Guide to Econometrics. Cambridge, MA: MIT Press (1998).

Kidwell, D. S.; E. H. Sorensen; and J. M. Wachowicz. "Estimating the Signalling Benefits of Debt Insurance: The Case of Municipal Bonds." Journal of Financial and Quantitative Analysis, 22 (1987), 399-313.

Lee, C. F., and O. M. Rui. "Does Trading Volume Contain Information to Predict Stock Returns? Evidence from China's Stock Markets." Review of Quantitative Finance and Accounting, 14 (2000), 341-360.

Leeth, J. D., and J. A. Scott. "The Incidence of Secured Debt: Evidence from the Small Business Community.” Journal of Financial and Quantitative Analysis, 24 (1989), 379-393.

Leland, H. E. "Agency Costs, Risk Management and Capital Structure." Journal of Finance, 53 (1998), 1213-1243.

Li, S.; F. Liu; S. Liu; and G. A. Whitmore. "Comparative Performance of Chinese Commercial Banks: Analysis, Findings and Policy Implications." Review of Quantitative Finance and Accounting, 16 (2001), 149-170.

Ma, Y. S. "The Chinese Route to Privatization-The Evolution of the Shareholding System Option." Asian Survey, 38 (1998), 379-397.

Ma, Y. W.; Z. J. Lin; and M. Z. Ma. Encyclopedia of Insurance Business (in Chinese). Beijing: China Financial Publishing House (1998).

Mayers, D., and C. W. Smith. "On the Corporate Demand for Insurance." Journal of Business, 55 (1982), 281-296.

Mayers, D., and C. W. Smith. "On the Corporate Demand for Insurance: Evidence from the Reinsurance Market.” Journal of Business, 63 (1990), 19-40. 
Mian, S. L. "Evidence on Corporate Hedging Policy.” Journal of Financial and Quantitative Analysis, 31 (1996), 419-439.

Myers, S. "The Capital Structure Puzzle.” Journal of Finance, 39 (1984), 575-592.

Myers, S., and N. Majluf. "Corporate Financing and Investment Decisions When Firms Have Information that Investors Do Not Have.” Journal of Financial Economics, 13 (1984), 187-221.

Newey, W., and K. West. "A Simple Positive Semi-Definitive, Heteroscedasticity and Autocorrelation Consistent Covariance Matrix." Econometrica, 55 (1987), 703-708.

Pei, X. "The Political Economy of Banking Reforms in China, 1993-1997.” Journal of Contemporary China, 7 (1998), 321-350.

Petersen, M. A., and R. G. Rajan. "The Benefits of Lending Relationships: Evidence from Small Business Data." Journal of Finance, 49 (1994), 3-47.

Pincus, M., and S. Rajgopal. "The Interaction between Accrual Management and Hedging: Evidence from Oil and Gas Firms.” Accounting Review, 77 (2002), 127-160.

Pittman, J. A., and S. Fortin. "Auditor Choice and the Cost of Debt Capital for Newly Public Firms." Journal of Accounting and Economics, 37 (2004), 113-136.

Rajan, R. G., and L. Zingales. "What Do We Know about Capital Structure? Some Evidence from International Data.” Journal of Finance, 50 (1995), 1421-1460.

Ritter, J. R., and I. Welch. "A Review of IPO Activity, Pricing, and Allocations." Journal of Finance, 57 (2002), 1795-1828.

Roy, A.; P. G. P. Walters; and S. T. K. Luk. "Chinese Puzzles and Paradoxes, Conducting Business Research in China." Journal of Business Research, 52 (2001), 203-210.

Saunders, A.; F. Strock; and N. Travlos. "Ownership Structure, Deregulation, and Bank Risk Taking." Journal of Finance, 45 (1990), 643-654.

Schmit, J. T., and K. Roth. "Cost Effectiveness of Risk Management Practices.” Journal of Risk and Insurance, 57 (1990), 455-470.

Smith, C. W. "On the Convergence of Insurance and Finance Research." Journal of Risk and Insurance, 53 (1986), 693-717.

Smith, C. W., and R. Stulz. "The Determinants of a Firm's Hedging Policies.” Journal of Financial and Quantitative Analysis, 20 (1985), 391-405.

Sun, Q., and W. H. S. Tong. "China Share Issue Privatization: The Extent of Its Success.” Journal of Financial Economics, 70 (2003), 183-222.

Thakor, A. V. "An Exploration of Competitive Signalling Equilibria with 'Third Party' Information Production: The Case of Debt Insurance." Journal of Finance, 37 (1982), 717-739.

Tian, G. H. "State Shareholding and the Value of China's Firms." Working Paper, London Business School (2001).

Villalonga, B., and R. Amit. "How Do Family Ownership, Control and Management Affect Firm Value." Journal of Financial Economics, 80 (2006), 385-417.

Wallace, R. S. O., and K. Naser. "Firm-Specific Determinants of the Comprehensiveness of Mandatory Disclosure in the Corporate Annual Reports of Firms Listed on the Stock Exchange of Hong Kong." Journal of Accounting and Public Policy, 14 (1995), 311-368.

Warner, J. B. "Bankruptcy Costs: Some Evidence." Journal of Finance, 32 (1977), 337-347.

Wei, Z.; F. Xie; and S. Zhang. "Ownership Structure and Firm Value in China's Privatized Firms: 1991-2001.” Journal of Financial and Quantitative Analysis, 40 (2005), 87-108.

Xiao, J. Z.; H. Yang; and C. W. Chow. "The Determinants and Characteristics of Voluntary Internetbased Disclosures by Listed Chinese Companies." Journal of Accounting and Public Policy, 23 (2004), 191-225.

$\mathrm{Xu}, \mathrm{X}$. N., and Y. Wang. "Ownership Structure and Corporate Governance in Chinese Stock Companies." China Economic Review, 10 (1999), 75-98.

Yamori, N. "An Empirical Investigation of the Japanese Corporate Demand for Insurance." Journal of Risk and Insurance, 66 (1999), 239-252.

Yermack, D. "Higher Market Valuation of Companies with a Small Board of Directors." Journal of Financial Economics, 40 (1996), 185-212.

Zou, H., and M. B. Adams. "The Corporate Purchase of Property Insurance: Chinese Evidence." Journal of Financial Intermediation, 15 (2006), 165-196.

Zou, H.; M. B. Adams; and M. J. Buckle. "Corporate Risks and Property Insurance: Evidence from the People's Republic of China.” Journal of Risk and Insurance, 70 (2003), 289-314.

Zou, H., and J. Z. Xiao. "Financing Decisions of Chinese Listed Companies." British Accounting Review, 38 (2006), 239-258. 